\title{
Hito Steyerl: três capítulos de Arte “Duty Free”: Arte na Era da Guerra Civil Planetária
}

\section{Hito Steyerl: Three Chapters of Duty Free Art: Art in the Age of Planetary Civil War \\ Hito Steyerl: três capítulos de Arte Duty Free: el arte en la era de la guerra civil planetaria}

palavras-chave: capitalismo; arte; tecnologia; política; globalização

keywords:

Capitalism; Art; Technology; Politics; Globalization

palabras clave: capitalismo; arte; tecnología; política; globalización
Hito Steyerl é artista, cineasta, escritora e professora de novas mídias na Universidade de Artes de Berlim. Sua produção investiga a circulação de imagens e informação digitais na contemporaneidade, refletindo criticamente acerca do mundo globalizado e suas perversidades. Com Arte "Duty Free": Arte na Era da Guerra Civil Planetária (em tradução livre), Steyerl aborda, em quinze capítulos, questões fundamentais que orbitam a função da arte e suas contradições no século XXI, o que fica evidenciado no próprio título da obra: "duty free" é o paraíso sem impostos dos aeroportos e também uma liberação de dado dever da arte, seja ele político, moral, social ou qualquer outro. Arte "Duty Free" foi publicado em inglês em 2017 pela editora Verso.

Hito Steyerl is an artist, filmmaker, writer, and professor of New Media Art at the Berlin University of the Arts. Her production investigates the circulation of digital images and information in contemporary times, reflecting critically on the globalized world and its perversities. With Duty Free Art: Art in the Age of Planetary Civil War (Verso, 2017), Steyerl addresses, in fifteen chapters, fundamental questions that orbit the function of art and its contradictions in the 21 st century. The title of the book evidences our situation: "Duty Free" is the tax-free paradise of airports and also a release from a given duty of art, be it political, moral, social or other.

Hito Steyerl es artista, cineasta, escritora y profesora de nuevos medios en la Universidad de Artes de Berlín. Su producción investiga la circulación 
de imágenes y información digitales en la contemporaneidad y refleje Hito Steyerl críticamente acerca del mundo globalizado y sus perversidades. Con Arte Duty Free: el arte en la era de la guerra civil planetaria (Caja Negra, 2018), Steyerl aborda, en quince capítulos, cuestiones fundamentales que orbitan la función Hito Steyerl: três capítulos de Arte "Duty Free":

Arte na Era da Guerra Civil Planetária

Os textos a seguir foram traduzidos e discutidos em reuniões do grupo de estudos Depois do fim da arte (Escola de Comunicações e Artes, Universidade de São Paulo - ECA/USP), coordenado por Dora Longo Bahia. Formado por estudantes, pesquisadores e professores de artes visuais, cinema, arquitetura, teatro e música, o grupo teve início no primeiro semestre de 2015, com o objetivo de pensar o sentido da produção artística atual e suas relações com os contextos políticos e culturais aos quais ela é contemporânea. O grupo partiu do problema colocado pela Internacional Situacionista de que a arte estaria ultrapassada para, a partir de então, promover encontros focados na discussão de textos e obras pertinentes à interrogação que se propõe, priorizando a produção de trabalhos práticos e desdobramentos públicos. 


\section{Capítulo 1: 0 Museu Nacional}

Este é um arquivo publicado em 2012 pelo WikiLeaks. É uma parte

Tradução: Alex Avelino e

Felipe Salem

Alex Avelino

(D) $0000-0003-2930-8749$

Felipe Salem D 0000-0001-9476-9117

* Duty free, em português, "isento de impostos" ou

"sem taxas", é um termo utilizado para designar mercadorias isentas de impostos - que normalmente seriam agregados a elas - ou espaços que as comercializam (duty free shop), geralmente localizados em aeroportos, aviões, entre outros. [N.T.]

1. 0 arquivo PowerPoint está anexado a um e-mail enviado ao Ministro dos Assuntos

Presidenciais com o assunto

"Presentation on the New

Vision for the Syrian Museums and Heritage Sites" lem tradução livre), apresentação da nova concepção para os Museus e Sítios Históricos da Síria), 30 de outubro de 2010, ID do e-mail 2089122.

Disponivel em: https:// wikileaks.org/syria-files/ docs/2089122 presentationon-the-new-vision-for-thesyrian- museums-and.html. Acesso em: 23 ago. 2020.

2. Entretanto, em 26 de junho de 2011, museus parceiros pediram o desmantelamento da estrutura institucional da iniciativa, a Syria Heritage Foundation. No início daquele mês, o Financial Times informou que a organização que integra o seu banco de dados de arquivos sobre a Síria. $\mathrm{O}$ arquivo, em formato PowerPoint, é chamado "316787_Vision Presentation-Oct 302010 Eng.pptx" e data de outubro de $2010^{1}$. Ele detalha os planos da primeiradama síria Asma al-Assad para o futuro dos museus do país. A fundação que ela propõe criar visa estabelecer uma rede de museus para promover o desenvolvimento social e econômico da Síria e fortalecer a identidade nacional e o orgulho cultural. O Louvre é citado como um parceiro no desenvolvimento desse projeto ${ }^{2}$. Tanto ele quanto o Guggenheim de Bilbao são mencionados como modelos para a reestruturação do Museu Nacional em Damasco.

Foi planejada uma conferência, a ser realizada em abril de 2011, para revelar o vencedor de uma competição internacional para o desenvolvimento do projeto desse Museu Nacional.

Entretanto, três semanas antes dessa data, vinte manifestantes foram "reportados mortos em um protesto de cem mil pessoas em Daraa" (COCKS, 2011). Até então, convites para a conferência já haviam sido feitos para uma lista de palestrantes conhecidos, incluindo os diretores do Louvre e do Museu Britânico. Em 28 de abril de 2011, a Art Newspaper publicou que o evento havia sido cancelado devido aos protestos nas ruas ${ }^{3}$. $\mathrm{O}$ vencedor do concurso de arquitetura para o projeto do Museu Nacional nunca foi revelado.

\section{Capítulo 2: nunca mais}

Para construir uma nação, Benedict Anderson sugeriu que deveria haver capitalismo de imprensa e um museu para narrar a história nacional e dar forma à sua identidade ${ }^{4}$. Hoje, em vez de imprensa, há o capitalismo de dados e uma grande quantidade de museus. Para construir um museu, uma nação não é necessária. Mas se nações são uma forma de organizar tempo e espaço, o museu também o é. Do mesmo modo que o tempo e o espaço se transformam, mudam-se também os espaços do museu. 


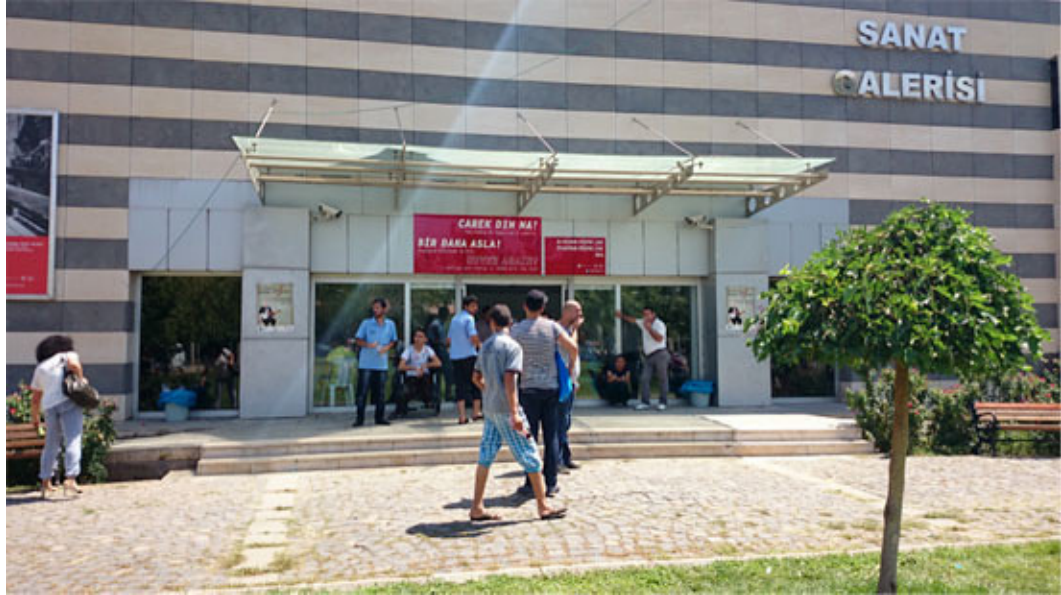

A imagem acima mostra a galeria municipal de arte de Diarbaquir, na Turquia. Em setembro de 2014, ela recebeu uma exposição sobre o genocídio e suas consequências chamada "Nunca Mais". Seu cartaz mostrava Willy Brandt, o antigo primeiro-ministro da Alemanha Oriental, de joelhos em frente ao memorial ao gueto de Varsóvia.

Mas a exposição não está em cartaz. Em vez disso, mais de 200 refugiados yazidis estão aglomerados na galeria.

Em agosto de 2014, depois que a milícia Daesh cruzou e aboliu definitivamente partes da fronteira entre a Síria e o Iraque (ASPDEN, 2012), por volta de cem mil refugiados yazidis fugiram da região de Sinjar, no norte do Iraque. A maioria deles cruzou a pé o Monte Sinjar, assistida por grupos rebeldes curdos que lhe abriram um corredor seguro. Enquanto a maioria ficava em campos de refugiados em Rojava, no norte da Síria, e em vários campos no norte do Iraque, muitos chegaram até as regiões curdas da Turquia, onde foram recebidos com uma hospitalidade extraordinária. A cidade de Diarbaquir fez da sua galeria municipal um abrigo emergencial.

Uma vez acomodados em tapetes no espaço da galeria, muitos refugiados começaram a pedir por cartões SIM para tentar contatar, pelo celular, familiares desaparecidos.

Esta é a mesa do curador, deixada vazia5.

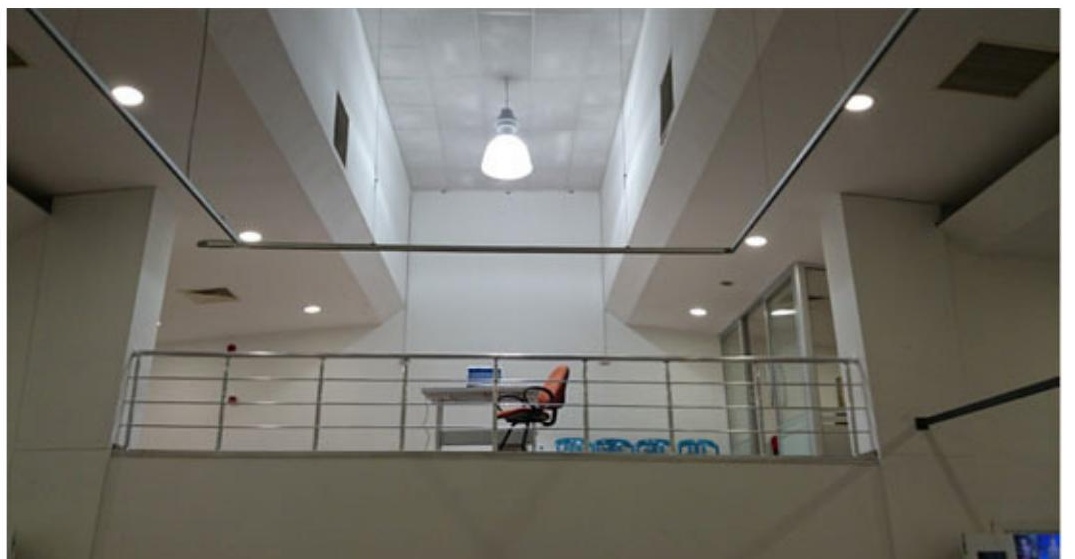

264

Hito Steyerl

Hito Steyerl: três capítulos de Arte "Duty Free":

Arte na Era da Guerra Civil

Planetária

havia suspendido as operações. Cf. SAIGOL (2011).

3. Cf. ANDERSON (2008) e o capítulo "O censo, o mapa e o museu", do mesmo livro.

4. 0 êxodo dos yazidis em Sinjar é contado em SLY (2014).

5. Seu nome é Barry Seyitvan.

Figura 1. Uma vista do exterior do Sümer Park Kültür Merkezi, em Diarbaquir, Turquia. Foto: Hito Steyerl.

Figura 2. Sümer Park Kültür Merkezi, em Diarbaquir, Turquia. Foto: Hito Steyerl. 
Em setembro de 2014, esse museu se tornou um campo de refugiados. Não representava uma nação, mas, em vez disso, pessoas desabrigadas fugindo de desintegrações nacionais.

\section{Capítulo 3: condições de possibilidades}

6. Da Wikipedia: "0 Google Ngram Viewer é um visualizador on-line, inicialmente baseado no Google Books, que transforma em gráfico a frequência de qualquer palavra ou frase curta usando a contagem anual de n-gramas encontrados em fontes impressas de 1800 a 2012 em qualquer uma das seguintes oito línguas: inglês americano, inglês britânico, francês, alemão, espanhol, russo, hebraico e chinês".

7. Osborne (2013) argumenta que a arte contemporânea expressa "a disjuntiva unidade dos tempos presentes [...]

Como um conceito histórico, o contemporâneo envolve, portanto, uma projeção de unidade na totalidade diferencial dos tempos que o homem vive" (tradução nossa).

8. Proxy, em português,

"procurador" ou "representante", é um servidor que age como intermediário para requisições de usuários com relação a outros servidores. Por ser um termo utilizado de forma corrente na linguagem técnica, foi mantido no original. [N.T.]
De acordo com o Google Ngram Viewer ${ }^{6}$, o uso do termo "impossível" caiu abruptamente por volta da metade do século XX. Mas o que isso nos diz? Significa que cada vez menos coisas são impossíveis? Significa que a impossibilidade "em si” está em seu declínio histórico? Ou talvez apenas signifique que as condições de possibilidades em si estão sujeitas a mudanças no tempo? Tanto o possível quanto o impossível são definidos por condições históricas e externas?

De acordo com Immanuel Kant, tempo e espaço são condições necessárias para perceber e entender qualquer coisa. Sem tempo e espaço, conhecimento, experiência e visão não se desdobram. Kant chama essa perspectiva de "crítica". Com isso em mente, que tipo de tempo e espaço são necessários para a arte contemporânea se manifestar? Ou então: o que a crítica de arte contemporânea diz hoje sobre tempo e espaço?

Resumindo brutalmente uma grande quantidade de textos acadêmicos: a arte contemporânea se torna possível por meio do capital neoliberal junto à internet, às bienais, às feiras de arte, a histórias pop-up paralelas e ao crescimento da desigualdade de renda. Vamos incluir nessa lista a guerra assimétrica - como uma causa da ampla redistribuição de riquezas -, a especulação imobiliária, a evasão fiscal, a lavagem de dinheiro e os mercados financeiros desregulamentados.

Parafraseando as ideias esclarecedoras do filósofo Peter Osborne sobre esse tema: a arte contemporânea revela a falta de tempo e espaço (globais). Além disso, projeta uma unidade ficcional em uma variedade de diferentes ideias de tempo e espaço, fornecendo, portanto, uma superfície comum onde não existe nenhuma ${ }^{7}$.

A arte contemporânea, portanto, se torna um proxy $^{8}$ para os bens globais, para a falta de qualquer território, temporalidade ou espaço comuns. Ela é definida por uma proliferação de localizações e pela falta de prestação de contas e funciona por meio de grandes operações imobiliárias que transformam cidades pelo mundo enquanto reorganizam o espaço urbano. É, inclusive, o espaço das guerras civis que promovem altas no mercado da 
é um termo que se refere a locais, normalmente próximos a portos e aeroportos, em que mercadorias em trânsito são isentas de impostos. [N.T.]

11. "Basta dizer que existe ampla crença entre comerciantes de arte, consultores e seguradoras de que há escondidas aqui obras

de arte o bastante para se criar um dos maiores museus do mundo" (tradução nossa). (SEGAL, 2012).

12. “De acordo com um documento confidencial, o freeport de Genebra geraria não menos que trezentos milhões de francos suíços de receita para o cantão" (tradução nossa).

13. As múltiplas implicações dessa noção para o pensamento político contemporâneo e a sua relação com o colapso gerenciado não podem ser subestimadas, não apenas em relação à tecnologia, mas também ao seu uso político: "Sua proveniência da engenharia foi sobreposta por um uso político neoconservador, por exemplo, por Condoleezza Rice, quando ela chamou as mortes entre a população civil e o caos

Página anterior

Figura 3. Sinalização do freeport de Genebra alertando os visitantes sobre seus cães de guarda. Foto: Hito Steyerl.
Há rumores de que esse prédio abriga milhares de Picassos, mas ninguém sabe o número exato deles, já que a documentação é bastante opaca. Existem poucas dúvidas, no entanto, de que seu conteúdo poderia competir com qualquer grande museu ${ }^{11}$.

Vamos partir do princípio de que esse é um dos espaços de arte mais importantes do mundo neste momento. Ele não somente é fechado ao público, como também se localiza em uma geografia muito interessante.

Do ponto de vista legal, os freeports de armazenamento de obras de arte são relativamente extraterritoriais. Alguns são considerados zonas de trânsito de aeroportos ou paraísos fiscais. Keller Easterling descreve a zona livre como um "enclave cercado para armazenamento" (EASTERLING, 2014). Isso agora se tornou um órgão principal do urbanismo global, copiado e colado em localidades pelo mundo todo. É um exemplo, nos termos de Easterling, de extraestadismo, incorporando uma "forma mestiça de exceção", além das leis do Estado-nação. Nesse estado de exceção desregulatório, corporações são beneficiadas às custas do cidadão comum, "investidores" tomam o lugar de contribuintes e módulos substituem edifícios: "Os atrativos dos freeports são similares àqueles oferecidos pelos centros financeiros offshore: segurança e confidencialidade, pouco escrutínio [...] e um arranjo de benefícios fiscais [...] As mercadorias nos freeports estão tecnicamente em trânsito, mesmo que, na realidade, esses portos sejam usados mais como abrigos permanentes de riqueza acumulada” (THE ECONOMIST, 2013).

O freeport é, portanto, uma zona de trânsito permanente.

Mesmo sendo fixo, o freeport também não define uma eterna efemeridade? É simplesmente uma zona extraterritorial, ou é também um setor desonesto cuidadosamente estabelecido para a obtenção de lucro ${ }^{12}$ ?

O freeport tem múltiplas contradições: é uma zona de impermanência terminal; é também uma zona extralegal legalizada, mantida por Estados-nação tentando emular países falidos tanto quanto possível - por meio da perda seletiva de controle. Thomas Elsaesser uma vez usou o termo "instabilidade construtiva" para descrever propriedades aerodinâmicas de jatos de combate que ganham vantagens decisivas por navegar no limite da falência do sistema (ELSAESSER, 2008) ${ }^{13}$. Eles poderiam mais ou menos "cair" ou "falhar" na direção desejada. Essa instabilidade construtiva é implementada em Estados-nação ao incorporar zonas onde eles "falham" de propósito. A Suíça, por exemplo, tem "245 entrepostos aduaneiros abertos" (O'MURCHU, 2015), incluindo zonas de exceção legais e administrativas. Esse estado e outros são um contêiner para diferentes tipos de jurisdições 
que são aplicadas - ou melhor, não são aplicadas - em relação às riquezas de indivíduos e corporações? Essa espécie de estado se torna um pacote para uma apatridia oportunista? Como aponta Elsaesser, toda sua ideia de "instabilidade construtiva” surgiu com a discussão sobre a obra Der Lauf der Dinge (1987), dos artistas suíços Fischli e Weiss. Aqui, todos os tipos de coisas são arrancados do equilíbrio por um colapso celebrativo. $\mathrm{O}$ grande mote do filme é:

"Am schönsten ist das Gleichgewitcht, kurz bevor's zusammenbricht"14

Entre tantas outras coisas, freeports também se tornaram espaços de arte $d u t y$-free, uma zona onde controle e falência são calibrados de acordo com a "instabilidade construtiva", de modo que as coisas fiquem alegremente suspensas em um equilíbrio frágil permanentemente congelado.

\section{Capítulo 4: arte duty-free}

Enormes espaços para armazenamento de obras de arte estão sendo criados ao redor do mundo naquilo que essencialmente poderia ser chamado de uma luxuosa terra de ninguém, paraísos fiscais onde obras de arte, uma vez negociadas, são transferidas de um armazém a outro. Eles são também um dos principais espaços da arte contemporânea: um museu offshore ou extraterritorial. Em setembro de 2014, Luxemburgo abriu seu próprio freeport. O país não é o único que tentou copiar o sucesso do freeport de Genebra: "Um freeport que abriu no Aeroporto Changi, de Singapura, em 2010, já está quase lotado. Mônaco também tem um. Um 'freeport de cultura' planejado em Pequim seria a maior instalação de armazenamento de obras de arte do mundo" (THE ECONOMIST, 2013). Um dos principais atores na instalação de muitos desses lugares é a transportadora de arte Natural Le Coultre, administrada pelo suíço Yves Bouvier.

Instalações de freeports de armazenamento de obras de arte são museus secretos. Suas condições espaciais se refletem em seus projetos. Em contraste com sua instalação suíça bastante superficial, os arquitetos superaram-se no freeport de Singapura:

\section{Hito Steyerl}

Hito Steyerl: três capítulos de Arte "Duty Free":

Arte na Era da Guerra Civil

Planetária

resultante durante a guerra Líbano-Israel, no verão de 2006, como consequência da 'instabilidade construtiva'" (tradução nossa).

14. Em tradução livre: 0 equilíbrio é mais belo justamente no ponto em que está para colapsar. [N.T.]

Página seguinte Figura 4. Contêineres no pátio da Natural Le Coultre, Zona Franca, Genebra. Foto: Hito Steyerl. 
15. Cf. BRATTON (2011).

Palestra no Berlage Institute,

na Holanda, e na École

Normale Superieure, em

Paris, em 2011, com o nome

de "On the Nomos of the

Cloud: The Stack, Deep

Address, Integral Geography",

que resultou em texto de

mesmo título de novembro

de 2011, anteriormente

disponível em bratton.info. A

palestra está disponível em:

https://www.youtube.com/ watch?v=XDRxNOJxXEE

“A Pilha, a megaestrutura, pode ser entendida como

uma confluência de sistemas de informação material complexos baseados em padrões interoperáveis, organizados de acordo com uma seção vertical, um modelo topográfico de camadas e protocolos.

A Pilha é uma seção universal padronizada. A

Pilha, como a encontramos e como eu a prototipei, é composta igualmente de camadas sociais, humanas e 'analógicas' (fontes de energia ctônica, gestos afetos, usuários-actantes, interfaces, cidades e ruas, salas e edifícios, envoltórios orgânicos e inorgânicos) e camadas informacionais, computacionais não humanas

e 'digitais' (cabos de fibra óptica multiplexados, centros de processamento de dados, bancos de dados, padrões e protocolos de dados, redes em escala urbana, sistemas

integrados, tabelas de enderecamento universal].
Projetado por arquitetos, engenheiros e especialistas em segurança suíços, a instalação de 82 quilômetros quadrados é parte bunker, parte galeria. Diferentemente dos freeports da Suíça, que ficam em armazéns protegidos, o FreePort de Singapura buscou combinar segurança e estilo. A entrada, as salas de exposição e o mobiliário foram projetados pelos designers contemporâneos Ron Arad e Johanna Grawunder. Uma escultura em arco gigantesca feita pelo Sr. Arad e chamada Cage sans Frontières [Jaula sem Fronteiras, em tradução livre] se espalha por toda a entrada. Pinturas que se alinham às paredes de concreto aparente dão à dependência um ar de galeria. Salas privativas e abóbodas, barricadas por portas de sete toneladas, se alinham nos corredores. Perto da entrada, galerias privativas dão a colecionadores a chance de ver ou mostrar a compradores potenciais suas obras com uma iluminação de qualidade museal. Uma segunda fase planejada irá dobrar o tamanho da instalação para 164 quilômetros. Os colecionadores são trazidos de seus aviões pela equipe do FreePort em limusines abastecidas com uísque, a qualquer hora do dia ou da noite, até a instalação. Se os clientes estiverem carregando bagagens, será providenciado um acompanhante armado. (PRYSTAY, 2010)

O título Jaula sem Fronteiras tem duplo sentido. Não significa apenas que a jaula não tem limites, mas também que a prisão agora está em todos os lugares, em uma dependência internacional de retiro de obras de arte que se infiltra pelas rachaduras da soberania nacional e se estabiliza em sua própria rede logística. Nessa prisão onipresente, regras ainda se aplicam, embora possa ser difícil especificar exatamente quais, para quem e a que elas se aplicam e como elas são implementadas. Quaisquer que sejam elas, sua aderência parece diminuir consideravelmente em proporção inversa ao valor dos ativos em questão. Mas essa construção não é somente um dispositivo realizado em uma localização específica do espaço tridimensional. É também uma pilha de operações jurídicas, logísticas, econômicas e baseadas em dados; uma pilha de plataformas que realizam mediações entre nuvens e usuários via leis estatais, protocolos de comunicação, padrões corporativos etc. e que se interconectam não somente por conexões de fibra óptica, mas também por rotas aéreas ${ }^{15}$.

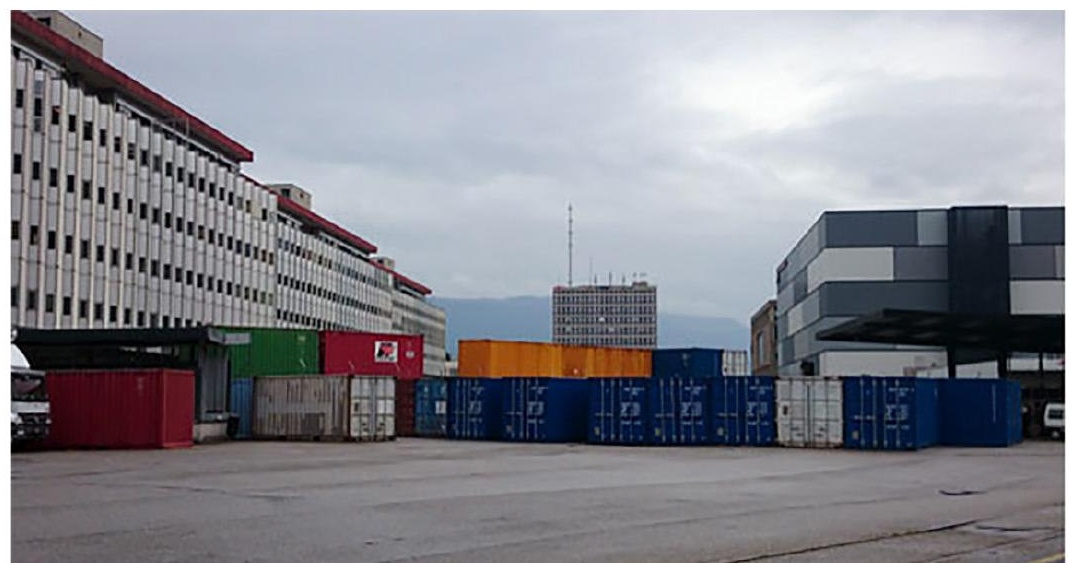


O armazém de arte freeport é para essa "pilha" o que o museu nacional tradicionalmente era para a nação. Ele se situa entre países em pontos de sobreposição de soberanias onde a jurisdição nacional se retraiu voluntariamente ou foi derrubada. Se bienais, feiras de arte, renderizações em 3D de propriedades gentrificadas, museus feitos por arquitetos-estrela decorando vários regimes etc. são as superfícies corporativas dessas áreas, os museus secretos são sua dark web ${ }^{16}$, sua Rota da Seda ${ }^{17}$, em que as coisas desaparecem, como em um abismo ${ }^{18}$.

Pense nas obras de arte e em seu movimento. Elas viajam dentro de uma rede de paraísos fiscais e também no interior dos espaços de armazenagem em si. Talvez, enquanto isso, elas nunca cheguem a ser desembaladas. Elas se movem de um espaço de armazenamento para outro sem serem vistas. Elas permanecem dentro de suas caixas e viajam por territórios internacionais com o mínimo de registros, como se fossem insurgentes, drogas, produtos financeiros derivativos e outros dos chamados veículos de investimento. Até onde sabemos, as embalagens podem até estar vazias. É um museu da era da internet, mas um museu da dark net ${ }^{19}$, onde o movimento é obscurecido e o espaço de dados é nebuloso.

Movimentos de um tipo bem diferente são detalhados nos arquivos do WikiLeaks sobre a Síria:

De: sinan@sinan-archiculture.com

Para:mansour.azzam@mopa.gov.sy

Enviado: Quarta-feira, 07 de julho de 2010 4:06 PM

Assunto: Fw: Itinerário de voo equipe $\mathrm{OMA}^{20}$

***ALTERAÇÃO ${ }^{* * * * *}$

Caro Sr. Azzam,

Isto é para confirmar a chegada do Sr. Rem Koolhaas e de seu assistente pessoal, Sr. Stephan Petermann, nesta segunda-feira, 12 de julho. Nós precisamos de vistos para eles, como falamos anteriormente (ambos são holandeses). As fotos de seus passaportes estão anexadas. Eles irão chegar separadamente e em horários diferentes. Sr. Koolhaas está vindo da China, através de Dubai pela Emirates airlines (chegando em Damasco às 16:25), enquanto Sr. Stephan Petermann está vindo de Viena pela Austrian airlines (chegando em Damasco antes do Sr. Koolhaas, às 15:00).

Eles ficarão hospedados no Art House ou no Four Seasons hotel até sua volta, na quinta-feira (às 16:00) $)^{21}$.
270

Hito Steyerl

Hito Steyerl: três capítulos de Arte "Duty Free":

Arte na Era da Guerra Civil

Planetária

Seus sistemas hard e soft* se misturam e trocam estados de fase, alguns se tornando mais 'hard' ou mais 'soft' de acordo com condições ocultas. (Serres, hard soft). Como cibernética social, A Pilha que conhecemos e projetamos compõe tanto o equilíbrio quanto a emergência, um oscilando com o outro em ritmo indecifrável e incalculável, territorializando e desterritorializando o mesmo componente para fins diagonais" (tradução nossa).

* Os termos hard lem português, "sólido", "rígido", "duro", "difícil") e soft ("suave", "macio", "sensível”) aqui também podem ter aplicação no contexto tecnológico e computacional em diálogo com conceitos empregados por Benjamin Bratton e por Michel Serres, autor mencionado por Bratton na citação da nota de rodapé. Segundo Steve Connor, professor na Universidade de Cambridge, em seu artigo "Michel Serres: The Hard and the Soft", "[...] o hard significa o dado, em oposição ao feito.

Significa o físico, em oposição ao conceitual. Significa hardware em oposição ao software. Significa objeto em oposição à ideia, forma em oposição à informação [...]" (tradução nossa). Portanto, optou-se por não os traduzir, a fim de preservar a dualidade hardware/software e sua relação com o campo da tecnologia, apesar de Serres 

de 2,5 milhões de e-mails de 680 domínios, ainda que a autenticidade

originalmente utilizar os termos dure doux, no francês, que podem ser traduzidos também por "duro"/"rígido" e "suave", respectivamente.

[N.T.]

16. Dark web, ou "internet obscura", em português, é a parte da rede mais profunda e de difícil acesso. Está relacionada a qualquer servidor de rede que seja inalcançável na internet por meio de configurações, softwares ou atualizações específicas. É a parte da rede que não pode ser

encontrada pelas ferramentas de busca comuns por estar encriptada, sendo, assim, por vezes também utilizada em atividades criminosas. Pode ser compreendida como uma pequena parte e o espaço mais profundo da deep web

- por sua vez, tudo aquilo que não pode ser encontrado livremente na internet e por usuários comuns, a parte não indexada pelos mecanismos de busca -, em oposição à surface web-a parte mais superficial da internet, $a$ world wide web, facilmente encontrada e acessada por mecanismos de pesquisa e por usuários comuns. [N.T.]

17. Silk Road, ou "Rota da Seda", era um mercado que operava por meio da dark net utilizando a rede Tor, ou The Onion Router lem português, "0 Roteador Cebola"), uma referência ao sufixo do domínio da desses documentos não tenha sido verificada pelo WikiLeaks. Pode ser verificado, entretanto, que a companhia de relações públicas Brown Lloyd James estava envolvida em tentar melhorar a imagem da família Assad (CARTER; CHOZICK, 2012). No início de 2011, pouco antes do começo da guerra civil síria, uma matéria da Vogue, profeticamente fotografada pelo fotógrafo de guerra James Nachtwey, retratava Asma al-Assad como a "Rosa do Deserto", uma modernizadora e patrona da cultura $^{22}$.

Em fevereiro de 2002, um ano após o início da guerra, Anonymous e organizações afiliadas hackearam o servidor de e-mail do Ministro de Assuntos Presidenciais da Síria em solidariedade a blogueiros sírios, manifestantes e ativistas (STONE, 2012) ${ }^{23}$. As caixas de e-mail de 78 assessores e conselheiros de Assad foram acessadas. Aparentemente, alguns usavam a mesma senha: "12345" (RAVID, 2012). Os e-mails vazados incluíam correspondências - a maior parte feita por intermediários - entre Mansour Azzam, o Ministro de Assuntos Presidenciais, e os escritórios de Rem Koolhaas (OMA), Richard Rogers e Herzog \& de Meuron sobre várias questões. Parafraseando o conteúdo de alguns e-mails: Roger e Koolhaas foram convidados para uma fala em Damasco e, no caso de Koolhaas, essas visitas se estenderam para discussões de projetos, incluindo o do Parlamento Nacional ${ }^{24}$. Herzog \& de Meuron ofereceram uma proposta de cortesia para o design da Casa de Cultura Al-Assad, em Aleppo, e expressaram interesse no processo seletivo para o projeto do parlamento ${ }^{25}$. Muitas dessas correspondências são apenas fofocas sobre os escritórios por meio dos intermediários. Também há muitas mensagens de spam. Nenhuma comunicação com nenhum escritório foi documentada após o final de novembro de 2010. Com as manifestações se iniciando em janeiro de 2011, uma revolta completa começou na Síria no fim de março desse ano. Todas as conversas e negociações entre oficiais e arquitetos parecem ter se interrompido quando o escrutínio do regime de Assad aumentou com o acúmulo de hostilidades reais. A autenticidade de nenhum desses documentos pode ser confirmada de modo independente, então, por enquanto, seus status são o de um conjunto de dados não armazenados, que podem ou não estar relacionados aos seus supostos autores e receptores ${ }^{26}$. Mas eles definitivamente são conjuntos de dados, hospedados pelos servidores 
do WikiLeaks, que podem ser descritos em termos de sua circulação, independente da proveniência e da autoria presumidas.

Vejamos a pintura War [Guerra] (2001), do artista Saif al-Islam Gaddafi. Saif é o filho do falecido líder da Líbia, Muammar Gaddafi, e era uma figura política na Líbia antes da deposição de seu pai por forças rebeldes apoiadas pelos ataques aéreos da Organização do Tratado do Atlântico Norte (OTAN), em 2011. Essa pintura foi exibida como parte de uma exposição chamada "O Deserto não é Silencioso", em Londres, em 2002.

Guerra retrata o bombardeio da OTAN na Iugoslávia, em 1999.

O artista escreve: "Uma guerra civil estourou em Kosovo, o que despedaçou a pintura e seu tema. O mar se agitou, fúria caiu dos céus, descendo sobre um fluxo de sangue" (BAILEY, 2011 ). Saif al-Islam disse em um depoimento na época: "Nós não apenas compramos armas e vendemos gás e petróleo como também temos cultura, arte e história" (NEBEHAY, 2011).

\section{Hito Steyerl}

Hito Steyerl: três capítulos de Arte "Duty Free":

Arte na Era da Guerra Civil Planetária

rede .onion e à técnica de anonimização do tráfego chamada onion routing, bem como ao sistema de criptografia camada por camada. É um software livre e de código aberto que permite a comunicação anônima ao navegar na internet, normalmente utilizado para proteção à privacidade, contra a censura e rastreamentos ou no acesso à dark web. Ficava

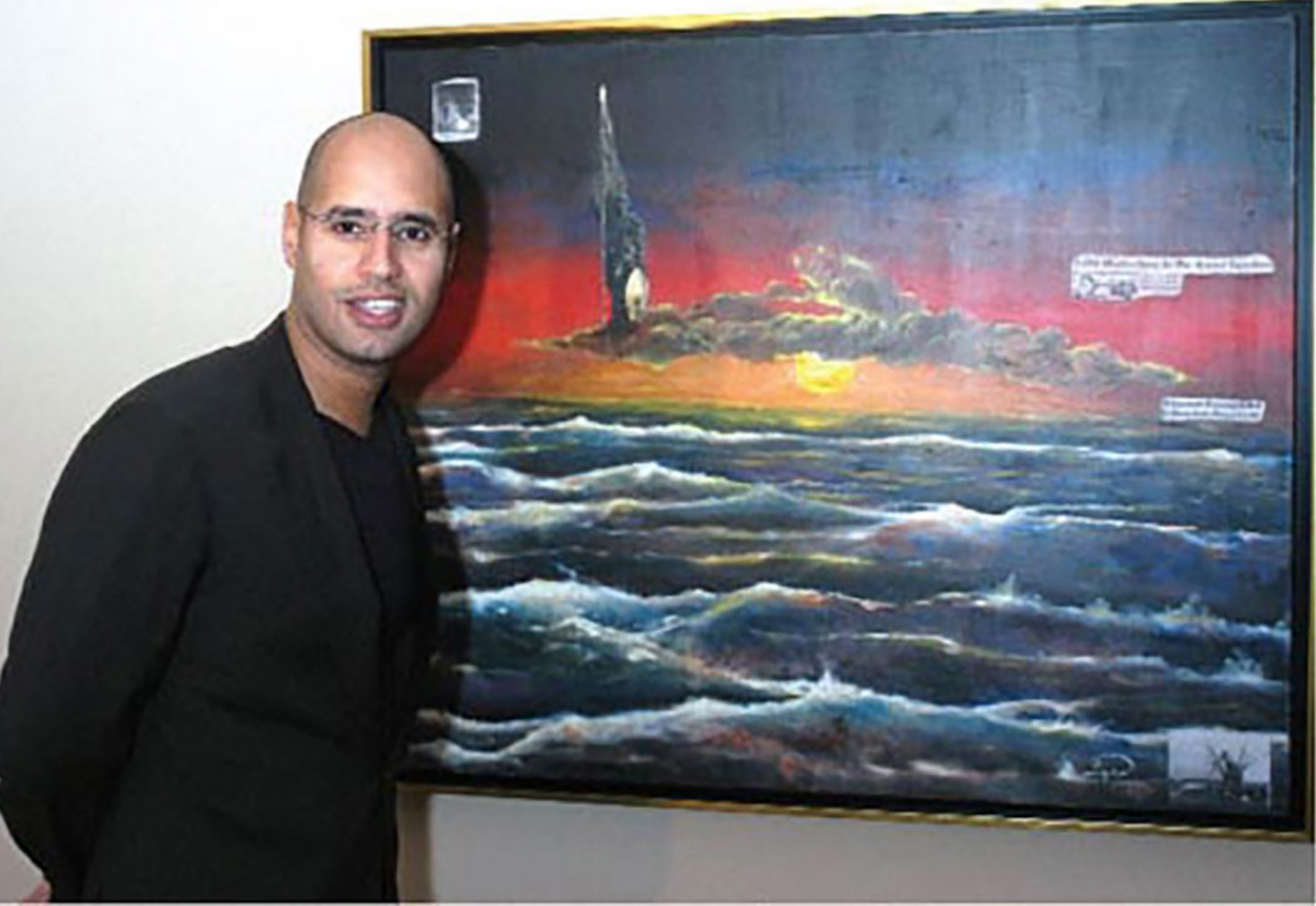


assegurado, assim, o anonimato de compradores e vendedores no comércio de produtos ilícitos. Esse termo foi apropriado de uma série de rotas interligadas no sul asiático que eram utilizadas para o comércio de seda entre o Oriente e a Europa. [N.T.]

18. Uma integrante da plateia em Moscou fez a observação extremamente inteligente de que isso seria visto como um grande benefício, pois muita "arte de mercado" de má qualidade seria colocada seguramente em quarentena sem que ninguém precisasse vê-la. Eu simpatizo muito com o ponto de vista dela.

19. Dark net é uma rede de computadores que utiliza a internet, mas que só pode ser usada por pessoas com permissão ou por determinados softwares. Refere-se também a sites difíceis de serem acessados, redes secretas ou paralelas à internet. [N.T.]

20. OMA é a sigla para Office for Metropolitan Architecture, em português, Escritório para Arquitetura Metropolitana. É um escritório de arquitetura com sede em Roterdã fundado em 1975 por Rem Koolhaas,

Elia Zenghelis, Madelon Vriesendorp e Zoe Zenghelis.

[N.T.]
Em setembro de 2010, o OMA expressou o desejo de trabalhar na Síria ${ }^{27}$. Um e-mail de Sinan Ali Hassan - arquiteto local que atuou como intermediário - para Mansour Azzam ostenta as vantagens de tal colaboração: "Rem foi supervisor e chefe de Zaha Hadid, além do fato de ele ser considerado mais importante (senão muito mais importante) que Lord Richard Rogers, em termos de celebridade e status profissional"28.

Da conversa entre o OMA e Sinan al-Hassan, fica claro que a proposta do OMA pode ser baseada em um projeto proposto anteriormente à Líbia: "Isso teria um escopo semelhante à visão do Saara líbio que mostramos a vocês e àquela que Rem discutiu com o presidente" ${ }^{29}$.

Em uma entrevista de junho de 2010, Koolhaas declarou que pessoas próximas a Saif al-Islam o abordaram (RUSCHTON, 2010) ${ }^{30}$. $\mathrm{Na}$ época, Saif era amplamente visto como um partidário de reformas. $\mathrm{O}$ projeto do OMA na Líbia gira em torno da preservação e foi exibido na Bienal de Veneza ${ }^{31}$. O projeto é posteriormente mencionado como um possível precedente a uma proposta de projeto para as regiões desérticas de Palmira, na Síria. Desde o levante, no início de 2011, essa área foi profundamente afetada pela subsequente guerra civil.

Atualmente, o Tribunal de Crimes Internacionais pediu a extradição de Saif Gaddafi da Líbia, onde ele permanece preso ${ }^{32}$.

\section{Capítulo 5: um sonho}

\section{AVISO: ESTE É O ÚNICO CAPÍTULO FICTÍCIO NESTA PALESTRA}

Para voltar à questão original: o que aconteceu com o tempo e o espaço? Por que eles estão quebrados e desarticulados? Por que o espaço está despedaçado em módulos de franquia tipo contêineres, dark webs, guerras civis e paraísos fiscais pelo mundo todo?

Com esses pensamentos em mente, eu adormeci e comecei a sonhar... e meu sonho foi muito estranho. Eu sonhei com alguns diagramas de um dos textos mais recentes de Peter Osborne. 

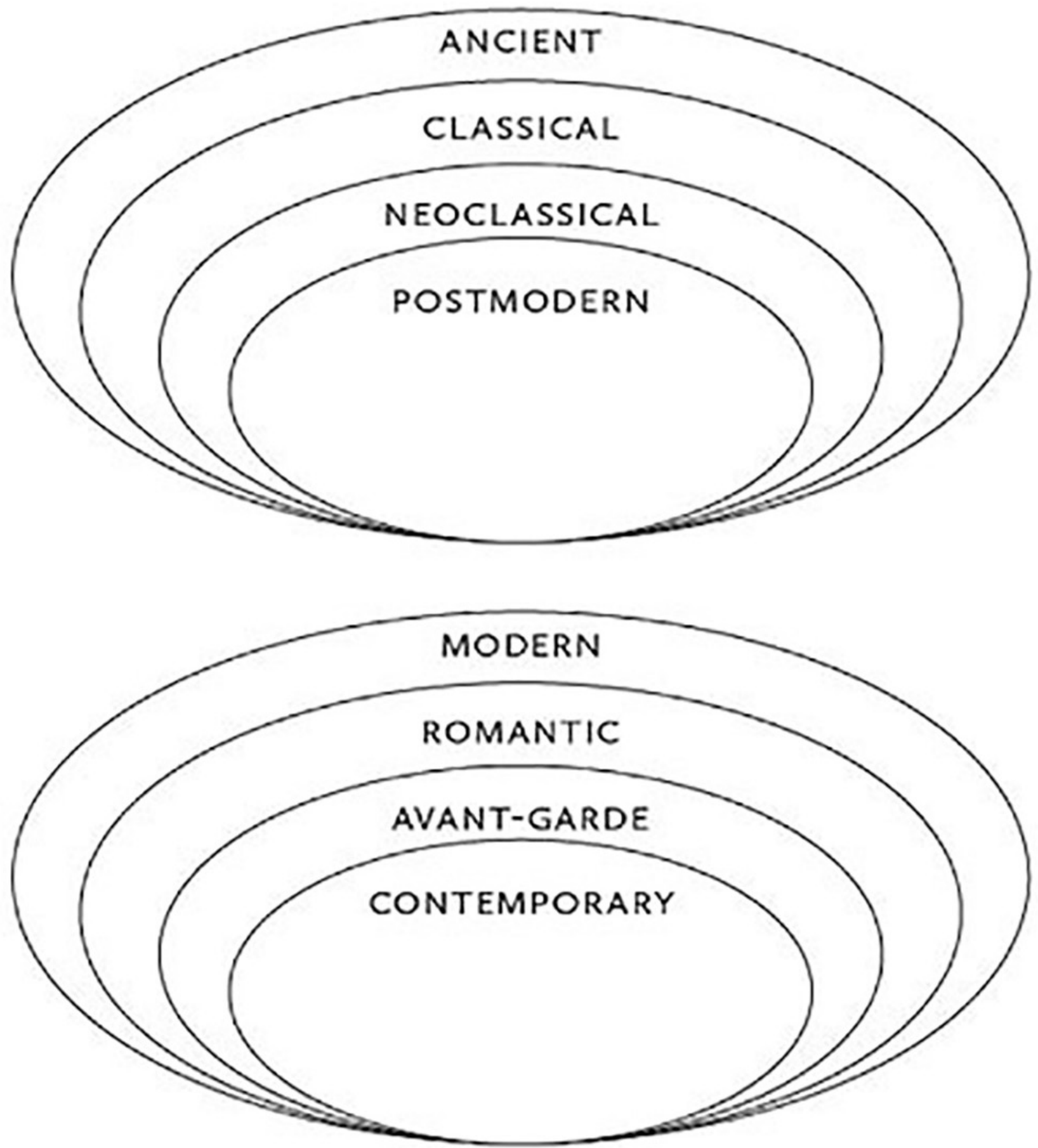

Figura 6. Aqui, uma genealogia da arte contemporânea é representada em diagrama pelo filósofo Peter Osborne. Fonte: Peter Osborne.

Página seguinte

Figura 7. Esquema gráfico representando uma mira. 
Eles descrevem uma genealogia da arte contemporânea; eu não estava focando em seu conteúdo, mas na sua forma. A primeira

21. Cf. https://wikileaks.org/ syria-files/docs/2089311 urgent.html. Acesso em: 23 ago. 2020 .

22. A história já foi retirada do ar. Mais informações podem ser encontradas em FISCHER

(2012) coisa que reparei foi que a sucessão de círculos concêntricos parecia indicar uma depressão ou uma ondulação, em todo caso, uma cavidade 3D. Mas por que o tempo e o espaço começariam a ficar flácidos, por assim dizer? Poderia ser um problema com a gravidade? Talvez um miniburaco negro poderia ter feito esses círculos se curvarem? Mas, novamente, é muito mais provável que alguma outra coisa tenha causado essa ondulação.

Repentinamente, eu descobri a resposta para essa questão. Eu comecei a perder gravidade e a voar pelo espaço. Peter Osborne estava flutuando por lá também e, com um improvável sotaque texano, ele

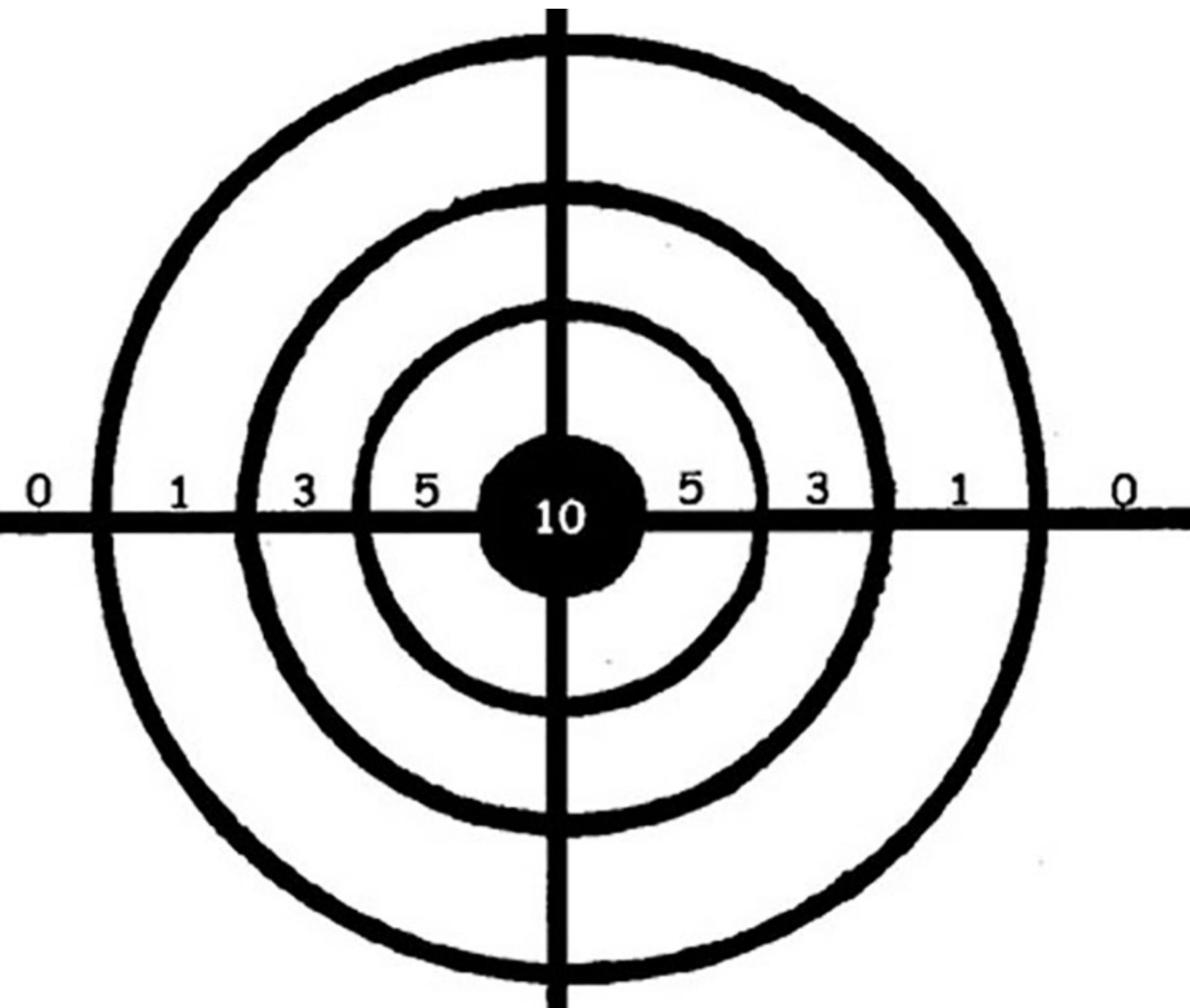


apontou para baixo e me mostrou esta mira.

Visto de cima, o diagrama de Peter se transformou em uma mira.

Se você olha de cima, a frágil cavidade desaparece. Torna-se uma tela plana. A partir de então, as pessoas simplesmente passaram a ver a genealogia da arte contemporânea nos diagramas de Peter em vez de uma depressão indicando que o alvo já fora atingido e que uma grande cratera se abrira no local do impacto.

Vista de cima, a genealogia da arte contemporânea agia como um proxy ou uma tela: uma visão para encobrir o local do impacto.

Por trás de seu visor de astronauta, Peter coaxou:

Esse é o papel da arte contemporânea. Ela é um proxy, um dublê. Ela é projetada em um local de impacto depois que o tempo e o espaço foram despedaçados em uma unidade disjuntiva - e prosseguem até colapsar em pilhas de arco-íris coloridos projetados por arquitetos-estrela.

A arte contemporânea é um tipo de camada ou proxy que finge que tudo ainda está bem, enquanto as pessoas estão cambaleando pelo efeito de tropas de choque, campanhas de medo, reality shows, cortes de eletricidade e qualquer outra forma de corte, GIFs de gatinho, gás lacrimogênio - todos os quais estão desmontando e religando completamente o aparato sensorial, assim como potencialmente as faculdades humanas de raciocínio e compreensão, causando um estado de choque e confusão, de depressão hiperativa permanente.

Você não sabe o que está acontecendo por trás das portas das salas de armazenamento freeport, sabe? Permita-me contar o que está acontecendo por lá: tempo e espaço são esmagados e rearranjados em pequenas peças como um acelerador de partículas bizarro, e o resultado é a jaula sem fronteiras chamada hoje de arte contemporânea.

\section{Hito Steyerl}

Hito Steyerl: três capítulos de Arte "Duty Free":

Arte na Era da Guerra Civil

Planetária

23. Este artigo cita a declaração inicial do Anonymous: "Enquanto as Nações Unidas permaneciam encostadas e teorizavam sobre a situação na Síria, o Anonymous tomou uma atitude. Ajudando blogueiros, manifestantes e ativistas a escapar da vigilância, na disseminação de mídia, interferindo nas comunicações e redes do regime, monitorando a internet síria em busca de perturbações ou tentativas de vigilância - travando uma campanha informativa e psicológica contínua contra Assad e seu governo assassino e genocida" (tradução nossa).

24. Cf. https://wikileaks.org/ syria-files/docs/2104601 important-follow-up.html Acesso em: 23 ago. 2020.

25. Cf. https://wikileaks.org/ syria-files/docs/2094815 fwd-al-asad-house-forculture-in-aleppo.html. Acesso em: 23 ago. 2020.

26. Herzog \& de Meuron foram contatados para comentar. mas não responderam até o momento em que este texto foi escrito. Para a resposta do escritório de Rem Koolhaas, OMA, veja abaixo.

27. "Rem Koolhaas está muito entusiasmado em visitar Damasco e tem grande interesse em atuar no setor público, na gentrificação 
ก. 39

urbana e regeneração

da cidade, tentando se

manter afastado dos

desenvolvimentos comerciais

e dos planos diretores

suburbanos. No entanto,

queríamos sentir as condições atuais de arquitetura e

urbanização da cidade antes de estabelecer qualquer compromisso. Eu também queria envolver Rem na escola

de arquitetura de Damasco

e estabelecer um programa de estágio entre o OMA e

a universidade" Itradução

nossa). Veja o e-mail completo aqui: https://wikileaks.org/ syria-files/docs/2092135

very-important.html. Acesso

em: 23 ago. 2020.

28. Ibidem.

29. Presidente sírio Bashar al-Assad. Ver e-mail completo aqui: https://wikileaks.org/ syria-files/docs/2091860 fwdhtml. Acesso em: 23 ago. 2020.

30. “Um novo cliente improvável é a Líbia, especificamente 'um grupo sutil de pessoas em torno do filho [Gaddafi] que deseja puxar o país em direção à Europa'" (tradução nossa)

31. A exposição do OMA na Bienal de Veneza de 2010 , intitulada CRONOCAOS,

incluiu uma seção no deserto da Líbia. A exposição foi baseada em "histórias críticas de preservação". Cf. "Rem Koolhaas / OMA * AMO in Venice: 2010", em www.art-it. 
Eu acordei em choque e percebi que estava lendo este PDF em voz alta.

\section{OMA}

Dr. Bashar al-Assad

President of the Syrian Republic

Rotterdam, $15^{\text {th }}$ Nowember 2010

Dear Mr. President,

Following our meeting in July and the subsequent request that we prepare an outline OMA/AMO approach for the strategic development of Al Badia, I am pleased to present you with the Al Badia Vision proposal for your review.

Our approach to this study begins with the conception of Al Badia as a unified entity within Syria. We envisage the region to act as a powerful resource for the benefit of the entire country while preserving its unique heritage. The Al Badia Vision creates a plan of action and of preservation for a set of subjects that are crucial to the region.

I am looking forward to meeting with you again to discuss the study as outlined in the attached proposal, which we trust demonstrates both our sincere interest in Syria and our capabilities to consider various challenges to the development of the region.

I will be visiting Syria during the fourth week of November for the purpose of giving a Public lecture in Damascus as well as to expand my knowledge and experience of your country. It would be a great pleasure to elaborate further with you on our prospective engagement with $\mathrm{N}$ Badia and other projects such as the National Parliament and other national and cultural projects during my stay.

Yours sincerely.

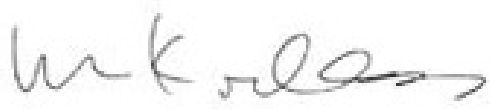

Rem Koolhaas

\section{Hito Steyerl}

Hito Steyerl: três capítulos de Arte "Duty Free":

Arte na Era da Guerra Civil

Planetária

32. Um mandado de prisão contra Saif Gaddafi foi emitido pelo TPI em 27 de junho de 2011. 
Caro Sr. Presidente,

Após a nossa reunião, em julho, e o subsequente pedido para prepararmos um esboço da abordagem do OMA/AMO para o desenvolvimento estratégico de Al Badia, é um prazer apresentar-lhe a proposta do Al Badia Vision para sua avaliação.

Nossa abordagem para esse estudo começa com a concepção de $\mathrm{Al}$ Badia como uma entidade unificada na Síria. Nós prevemos que a região atuará como um poderoso recurso em benefício de todo o país enquanto preserva sua herança única. $\mathrm{O}$ Al Badia Vision cria um plano de ação e de preservação para um conjunto de assuntos que são cruciais para a região.

Estou ansioso para encontrá-lo novamente para discutirmos o estudo, conforme descrito na proposta anexa, que acreditamos demonstrar tanto nosso sincero interesse na Síria quanto nossas capacidades para considerar os vários desafios ao desenvolvimento da região.

Figura 9. Este gráfico mostra o índice Dow Jones Industrial Average durante a queda, no dia 23 de abril de 2013, causada por um tweet falso na Associated

Press, inserido à esquerda. Fonte: "Syrian hackers claim AP hack that tipped stock market by $\$ 136$ billion. Is it terrorism?", Washington Post, 23 abr. 2013.
Eu irei visitar a Síria durante a quarta semana de novembro com o objetivo de dar uma palestra pública em Damasco, bem como expandir minha experiência no seu país e meu conhecimento sobre ele. Seria um grande prazer elaborar mais profundamente com você o nosso futuro compromisso com Al Badia e outros projetos, tal como o do Parlamento Nacional, e demais projetos nacionais e culturais durante a minha estadia.

Com os melhores cumprimentos,

Rem Koolhaas

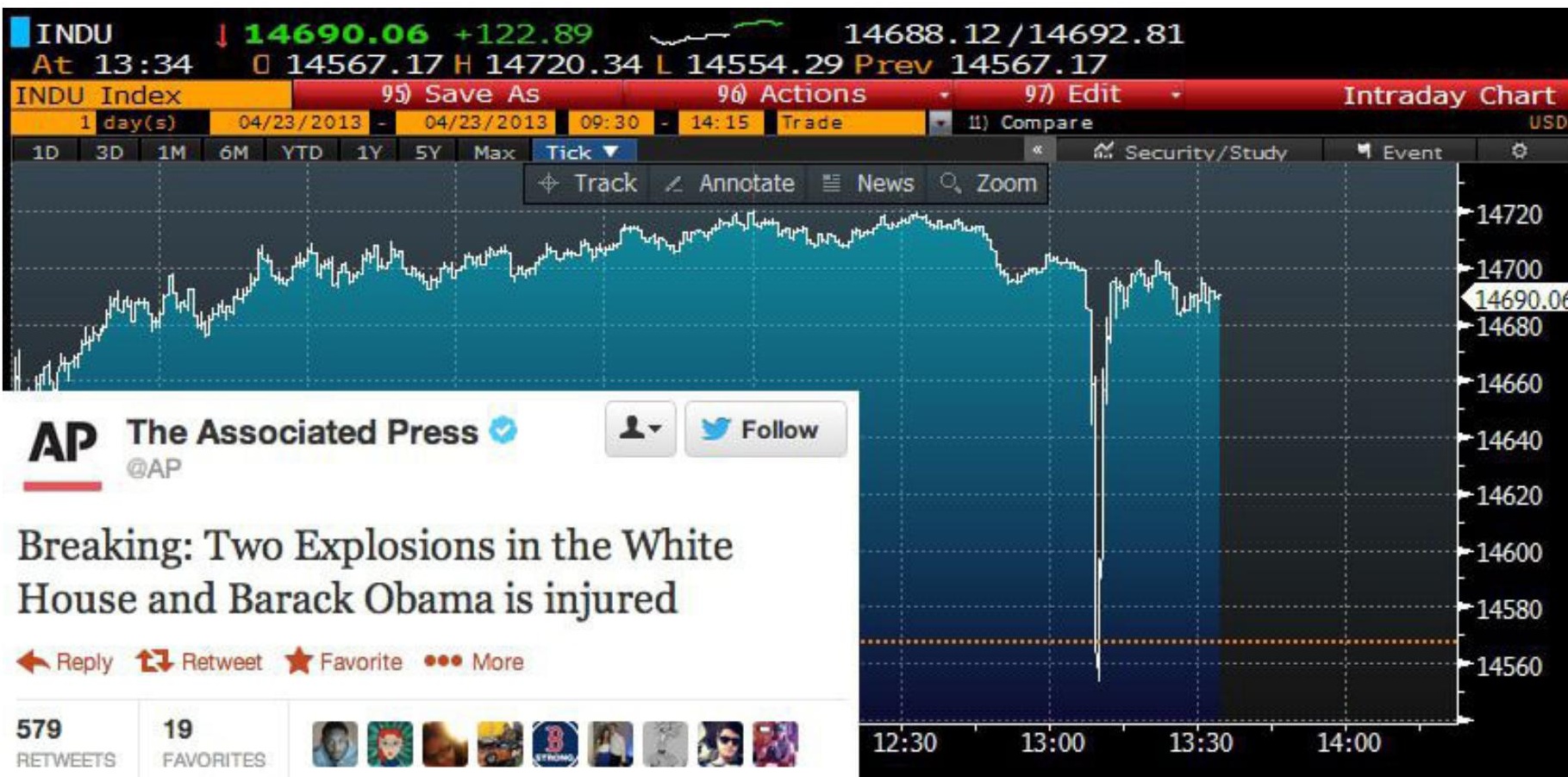




\section{Capítulo 6: e agora para Justin Bieber}

O feed do Twitter do E! Online, em 4 de maio de 2013, mostra alguém posando como Bieber e deixando escapar triunfantemente: "Eu sou gay".

Como você pode perceber, o Exército Eletrônico Sírio (EES) hackeou essa conta do Twitter.

Quem é o EES? É um grupo de hackers a favor do regime de Assad. Ele também hackeou o Le Monde, na França, no início de 2015. Antes disso, o EES havia invadido os websites do The New York Times, The Washington Post e a divisão de recrutamento do Corpo de Fuzileiros Navais dos Estados Unidos. O grupo também hackeou a conta do Twitter da Associated Press (AP) e divulgou uma notícia falsa sobre um bombardeio na Casa Branca (HARRIS, 2013) ${ }^{33}$.

O diagrama acima mostra as consequências desse tweet em Wall Street. Em três minutos, a "notícia falsa apaga \$136 bilhões em valores no mercado de ações" (FISHER, 2013).

O grupo Anonymous da Síria e seus múltiplos aliados hackearam o Exército Eletrônico Sírio e despejaram coordenadas de supostos membros na dark web (STUART, 2013). O espaço de dados da Síria está sob ataque, hackeado, fragmentado. Além disso, ele se estende da AP à Wall Street, a servidores russos e australianos, assim como às contas do Twitter de uma revista de celebridades. Estende-se até os servidores do WikiLeaks, onde os arquivos sobre a Síria estão hospedados, e que tiveram que mudar de localização várias vezes anteriormente, após terem sido retirados da Amazon em 2010. Houve rumores de que o WikiLeaks tentou mover seus servidores para uma localidade offshore, uma antiga plataforma de petróleo extraterritorial chamada Sealand (KEATING, 2012). Isso teria de fato replicado o cenário do freeport de um ângulo diferente.

Mas para colocar uma questão mais geral: como a internet, ou, mais precisamente, operações on-line entre diferentes bancos de dados afetam as construções físicas dos museus - ou sua impossibilidade física?
Hito Steyerl

Hito Steyerl: três capítulos de Arte "Duty Free":

Arte na Era da Guerra Civil

Planetária

33. Para mais detalhes, consulte este interessante relatório: SCOTT-RAILTON; MARQUIS-BOIRE (2013). 


\section{Capítulo 7: um e-mail enviado da Suíça e sua resposta}

ano 18

ก. 39

De: Hito Steyerl mailto:xy@protonmail.ch

Data: Terça-feira, 17 de fevereiro de 2015 8:05 PM

Para: Recepção

Assunto: Pedido de confirmação de autenticidade

Caros Senhores,

Eu gostaria gentilmente de lhes pedir para confirmarem a autenticidade das várias comunicações por e-mail entre o OMA/AMO e oficiais do governo sírio e intermediários publicados pelo WikiLeaks como parte de seus "Arquivos sobre a Síria".

Eu sou uma cineasta e escritora que mora em Berlim e estou trabalhando em uma palestra sobre as transformações dos museus nacionais sob as condições da guerra civil, tanto em dados quanto no espaço físico 3D.

Não tenho intenções de escandalizar a comunicação entre o OMA e o Ministério de Assuntos Presidenciais da Síria. Minha intenção é questionar como a comunicação por internet e o (quase) colapso de alguns países afetam o planejamento dos espaços museológicos contemporâneos.

Nesse contexto, seria interessante saber mais sobre as circunstâncias que causaram o fim das discussões do projeto na Síria. Eu tenho certeza de que o escritório dos senhores teve seus motivos para isso e seria ótimo poder incluí-los na discussão.

Abaixo está uma lista de links que pretendo citar.

Meus cumprimentos,

\section{Hito Steyerl}

https://wikileaks.org/syria-files/docs/2089311_urgent.html https://wikileaks.org/syria-files/docs/2092135_very-important.html https:/wikileaks.org/syria-files/docs/2091860_fwd-.html https://wikileaks.org/syria-files/attach/319/319092_101115_ Rem\%20Koolhaas\%20letter.pdf

Enviado pelo ProtonMail, e-mail criptografado com base na Suíça:

RE: Pedido de confirmação de autenticidade

De: Jeremy Higginbotham <xy@oma.com>

Para: Hito Steyerl <xy@protonmail.ch>

Em 26/02/2015 7:13 am

Cara Hito Steyerl,

Obrigado pelo seu e-mail. Nós não temos como confirmar a autenticidade dos documentos relacionados abaixo.

Entretanto, lhe desejamos boa sorte com o seu trabalho. 


\author{
Nossos melhores cumprimentos, \\ Jeremy Higginbotham \\ Chefe de Relações Públicas
}

\section{OMA}

Desde o vazamento provocado por Edward Snowden, comecei a usar o ProtonMail, uma iniciativa dos pesquisadores da Organização Europeia de Pesquisas Nucleares (CERN), que estão gentilmente fornecendo uma plataforma de e-mail criptografada. Assim é como eles descrevem seu projeto, usando o mapa da Suíça:

Toda a informação nos servidores do ProtonMail é armazenada na jurisdição do Tribunal Cantonal de Genebra, com as vantagens das leis de privacidade da Suíça e do Cantão.

Toda a informação nos servidores do ProtonMail é armazenada na jurisdição do Tribunal Cantonal de Genebra, com as vantagens legislativas de privacidade da Suíça e do Cantão.

Mas a resposta amigável do OMA/AMO não é armazenada em um free-port, é armazenada apenas segundo as leis "normais" da jurisdição suíça em um antigo centro militar nas profundezas dos alpes suíços ${ }^{34}$. Essa é a jurisdição e a criptografia que uso para tentar provocar qualquer interferência governamental potencial com alguns dos meus dados apenas um pouco mais incômodos. Na verdade, estou aproveitando as proteções legais que permitiram evasão fiscal e lavagem de dinheiro em escala espantosa por meio de bancos e outras instalações suíças ${ }^{35}$. Por outro lado, o mero uso de ferramentas on-line de privacidade sinaliza usuários para o escrutínio da $\mathrm{NSA}^{36}$, efetivamente revertendo o efeito desejado ${ }^{37}$. A tela do anonimato se tornou um dispositivo paradoxal.

O efeito ambíguo das políticas destinadas a aumentar o anonimato também figura em um nível diferente da atividade freeport.

Em 25 de fevereiro de 2015, promotores de Mônaco prenderam Yves Bouvier, o proprietário da Natural Le Coultre - empresa envolvida com os freeports de Luxemburgo, Genebra e Singapura -, por atividades suspeitas de fraudes na arte: "Acredita-se que a investigação está centralizada nos preços inflacionários de enormes transações de obras de arte em que Bouvier era o intermediador" (CHRISAFIS, 2015) ${ }^{38}$. Bouvier supostamente se aproveitou do fato de que grande parte das obras de
282

Hito Steyerl

Hito Steyerl: três capítulos de Arte "Duty Free":

Arte na Era da Guerra Civil

Planetária

34. Informações no site protonmail.ch sob o título: segurança suíça. Acesso em: 23 ago. 2020.

35. Para um exemplo recente, cf. TREANOR (2015).

36. NSA, ou National Security Agency lem português, Agência Nacional de Segurançal, é uma agência de inteligência que faz parte do Departamento de Defesa dos Estados Unidos e desempenha funções relacionadas à interceptação de sinais de comunicação entre pessoas e máquinas, bem como da criptoanálise de material criptografado, sendo também responsável pela segurança das comunicações estadunidenses. [N.T.]

37. Essa ambiguidade caracteriza as ferramentas populares da web que deveriam proteger 0 anonimato, como o Tor. Os vazamentos de Edward Snowden revelaram que 0 mero uso do Tor, ou mesmo a pesquisa na web por ferramentas de proteção de privacidade, sinalizam as pessoas para o escrutínio da NSA. Cf. "NSA targets the privacy-concious", em daserste.ndr.de. Acesso em: 23 ago. 2020. Um software destinado a ocultar a vigilância acaba a atraindo.

38. Cf. também LE TEMPS (2015a). Bouvier rejeitou 
arte armazenadas nos freeports pertencem às chamadas sociétés écran (na tradução literal, "empresas de tela"). Já que as transações foram feitas

as alegações, colocando a

culpa de volta no oligarca russo supostamente fraudado, Dmitry Rybolovlev. através desses proxys anônimos, compradores e vendedores não estavam aptos a se comunicar e controlar o valor da comissão cobrada (LE TEMPS, 2015b). A tela que supostamente deveria providenciar o anonimato dos proprietários pode também trabalhar contra eles. Invisibilidade é uma tela que às vezes funciona em dois sentidos - embora nem sempre. Ela funciona a favor de quem está no controle da tela.

\section{Capítulo 8: atirando em relógios - o museu público}

Como comentado anteriormente, Benedict Anderson sugere que, para construir uma nação, deveria existir capitalismo de imprensa e um museu. Hoje em dia, não é impossível construir um museu sem uma nação. Nós podemos até olhar para isso de modo mais geral e ver tanto nações quanto museus como nada mais que um outro modo de organizar tempo e espaço; nesse caso, estraçalhando-os em pedaços.

Mas o tempo e o espaço não são estraçalhados sempre que um novo paradigma para um museu é criado? Isso ocorreu de fato na Revolução Francesa de julho de 1830, cuja história Walter Benjamin (1987) nos conta. Revolucionários estavam atirando em relógios. Eles também haviam subvertido o calendário, renomeando os meses e alterando sua duração.

E esse é o período em que o Louvre foi invadido mais uma vez como durante todas as grandes revoltas em Paris durante o século XIX. O protótipo de um museu público foi criado quando tempo e espaço haviam sido estraçalhados e novamente fundidos. O Louvre foi criado por ter sido invadido. Foi invadido em 1792 durante a Revolução Francesa e se transformou, de uma coleção feudal de despojos - uma versão histórica dos freeports de armazenamento de obras de arte-, em um museu público de arte, provavelmente o primeiro do mundo, introduzindo um modelo de cultura nacional. Mais tarde, ele se tornou o carro-chefe de um império colonial que tentou de maneira autoritária semear essa cultura em outros lugares, antes de tentar criar, mais recentemente, franquias em estados feudais, ditaduras e combinações dos mesmos.

Entretanto, o atual Museu Nacional da Síria é de uma ordem diferente. Contrário aos planos inspirados pelo "efeito Bilbao”, o museu 
é hospedado on-line, em incontáveis servidores em vários lugares. Como Jon Rich eAli Shamseddine notaram, ele é uma coleção de vídeos on-linede documentos e gravações de inúmeras matanças, atrocidades e ataques que permanecem ainda sem terem sido vistos (SHAMSEDDINE; RICH, 2014). Esse que é de fato o Museu Nacional da Síria, não uma franquia do Louvre adquirida pela Fundação Assad. Esse arquivo acidental de vídeos e outros documentos é feito de diferentes gêneros e estilos, mostrando pessoas revirando destroços ou decapitações aceleradas em HD no Twitter. Ele mostra ataques aéreos de baixo, não de cima. Os documentos e gravações produzidos do chão acabam em uma variedade de servidores ao redor do mundo. Eles estão disponíveis - em teoria - em qualquer tela, exceto nos lugares em que foram feitos, onde o upload de algo no YouTube pode fazer com que pessoas sejam mortas. Essa inversão espaço-temporal é quase como o reverso das coleções de arte reunidas nos freeports.

A totalidade desse arquivo não está adaptada à percepção humana, ou pelo menos não à percepção individual. Como todo banco de dados de larga-escala - incluindo os arquivos do WikiLeaks sobre a Síria -, ele toma a forma de uma imensidão de informações sem (ou com muito pouca) narrativa, fundamentação ou interpretação. Pode ser parcialmente visível para o público, mas não é necessariamente inteligível por completo. Permanece parcialmente inacessível, não por meio de exclusão, mas porque sobrecarrega a capacidade de percepção e de atenção de qualquer indivíduo ${ }^{39}$.

\section{Capítulo 9: autonomia}

Vamos voltar aos exemplos mencionados no começo: os espaços freeports de armazenamento de obras de arte e a galeria municipal de arte de Diarbaquir, que se transformou em um campo de refugiados. Um espaço retira as obras de arte do mundo, acumulando-as, enquanto o outro basicamente abrigou os fugitivos de estados em colapso. Como e onde a arte pode ser mostrada publicamente, no espaço físico 3D, sem colocar em risco seus autores e ao mesmo tempo levando em conta as vertiginosas mudanças temporais e espaciais expressas por esses dois exemplos? Que forma poderia tomar um novo modelo de museu público, e como a noção de "público" em si se transformaria radicalmente no
Planetária

39. Observe as diferentes estratégias para divulgar vazamentos maciços empregados, por um lado, pelo WikiLeaks e, por outro, por Edward Snowden, Laura Poitras, Glenn Greenwald e seus inúmeros colaboradores. 
40. Mais enfaticamente expresso por BÜRGER (2017).

41. Que podem cumprir o papel tradicional de uma

"lápide financeira" [no original, financial tombstone] - um gadget que comemora transações concluídas. Ver a entrada no Wikipedia para

"Deal toy".

42. Apesar da expressão debt bondage, no original, referir-se à "servidão" ou “escravidão" por dívida, o uso do termo bondage pela autora também é carregado de outros significados. Além do sentido de propriedade ou da relação de poderdesamparo, o termo pode ser incluído no universo das práticas sexuais, a exemplo do modo como foi explorado por Steyerl em trabalhos como Lovely Andrea (2007), em que a artista exibe sua tentativa de reencontrar uma fotografia realizada em Tóquio quando ainda era estudante e havia posado como modelo de bondage. No trabalho, a artista aborda questões sobre política, o corpo feminino, cultura popular e a difusão de imagens em um mundo digital. [N.T.]

43. Do original, High Net Worth Individuals, ou HNWI, termo usado por instituições

financeiras para designar pessoas com alto patrimônio líquido. Normalmente, possuem ativos financeiros estoque de arte duty-free. Minha sugestão não é evitar ou menosprezar essa proposta, mas levá-la ainda mais adiante.

A ideia de arte duty-free tem uma grande vantagem em relação ao modelo cultural de Estado-nação: a arte duty-free não deveria ter nenhum dever para executar, para representar, para ensinar, para incorporar valor. Não deveria estar em débito com ninguém, não deveria servir a uma causa ou a um mestre, nem ser o meio para coisa alguma. Arte $d u t y$-free não deveria ser um meio para representar uma cultura, uma nação, dinheiro ou qualquer outra coisa. Até a arte duty-free dos armazéns freeport não é duty-free; é somente livre de impostos. Tem o dever de ser um ativo.

Vista deste modo, a arte $d u t y$-free é, em essência, o que a arte autônoma tradicional poderia ter sido se não fosse elitista e alheia às suas próprias condições de produção ${ }^{40}$.

Mas arte duty-free é mais do que uma reedição da velha ideia de arte autônoma. Ela também transforma o significado desgastado do conceito de "autonomia artística". A arte autônoma, sob as atuais circunstâncias espaciais e temporais, precisa levar em consideração essas condições de tempo e espaço. As condições de possibilidade da arte não são mais apenas a "torre de marfim" elitista, mas também a fundação de arte contemporânea do ditador, o esquema de evasão fiscal de oligarquias/fabricantes de armas, prêmios de fundos de cobertura ${ }^{41}$, a servidão por dívida ${ }^{42}$ dos estudantes de arte, uma imensidão de dados vazados, spams acumulados e o produto de uma enorme quantidade de trabalho "voluntário" não remunerado - tudo o que resulta no acúmulo de obras de arte em cubículos freeport, bem como em sua destruição física em zonas de guerra ou sua privatização acelerada.

A arte autônoma, nesse contexto, poderia tentar entender a autonomia política como um experimento na construção de alternativas a um modelo de Estado-nação que continua proclamando a cultura nacional enquanto, simultaneamente, pratica a "instabilidade construtiva", por meio da inclusão de comunidades fechadas para indivíduos de alto patrimônio líquido ${ }^{43}$, como miniversões de estados falidos. Para voltar ao exemplo da Suíça: esse país é tão impregnado por enclaves extraterritoriais 
com regulamentos reduzidos que poderia ser mais precisamente definido como uma entidade x-por cento desonesta dentro de uma sólida indústria de relógios. Mas a técnica extraestadista pode também ser definida como uma autonomia política sob circunstâncias completamente distintas e com resultados muito diferentes, como os experimentos recentes em autonomia de Hong Kong a Rojava demonstraram.

Mas a arte autônoma pode até ser arte liberta, tanto de seus autores quanto de seus proprietários. Lembram-se da desresponsabilização do OMA? Agora imaginem toda obra de arte em freeports sendo certificada pelo texto: "Eu não tenho como confirmar a autenticidade desta obra de arte".

Esse é o Centro Cultural em Suruç, na Turquia. Fica do outro lado da fronteira da cidade de Kobanê, centro administrativo do cantão autônomo de mesmo nome, que fica localizado na região de Rojava, no norte da Síria. Não é coincidência que as entidades autônomas em Rojava se chamem cantões: elas foram modeladas a partir dos cantões suíços - para enfatizar o papel que a democracia de base desempenhou na sua fundação inicial ${ }^{44}$.

Após o ataque ao Cantão de Kobanê por soldados Daesh em setembro de 2014, o Centro Cultural foi temporariamente transformado em outro campo de refugiados, hospedando várias centenas de pessoas que fugiram da região sitiada nos arredores de Kobanê.

Um ano depois, ele foi atingido por um ataque suicida do Daesh que matou mais de trinta ativistas. Esse incidente foi o começo de uma com valor mínimo superior a um milhão de dólares. [N.T.]

\section{Por mais limitada que} possa ter sido sua democracia de base, dado que o sufrágio feminino generalizado não foi concedido até 1971 e, em Appenzell Interior, até 1990.

Figura 10. 0 Centro Cultural em Suruç, na Turquia, aqui representado, está na fronteira com a cidade de Kobanê, o centro administrativo do cantão autônomo com o mesmo nome, localizado na região de Rojava, no norte da Síria. Foto: Hito Steyerl. 

ano 18 arrasados e expropriados sob um estado de exceção que agora se tornou

ก. 39 semipermanente.

Durante o mesmo período, artefatos arqueológicos saqueados de Palmira, na Síria, foram recuperados no freeport de Genebra. 


\section{Bibliografia}

ANDERSON, Benedict. Comunidades imaginadas: reflexões sobre a origem e a difusão do nacionalismo. São Paulo: Companhia das Letras, 2008.

ASPDEN, Peter. The walls of ignorance. Financial Times, 9 jun. 2012.

BAILEY, Martin. Gaddafi's son revealed true colors. Art Newspaper, 2 de mar. 2011.

BENJAMIN, Walter. Teses sobre o conceito da história. In: BENJAMIN, Walter. Magia e técnica, arte e política. Ensaios sobre a literatura e história da cultura. $3^{a}$ ed. São Paulo, Brasiliense, 1987, pp. 222-232.

BRATTON. On the Nomos of the Cloud: The Stack, Deep Address, Integral Geography. Berlage Institute, 28 nov. 2011. Disponível em: https://www.youtube.com/watch?v=XDRxNOJxXEE. Acesso em: 26 ago. 2020.

BÜRGER, Peter. Teoria da vanguarda / trad. José Pedro Antunes. São Paulo: Ubu, 2017.

CARTER, Bill; CHOZICK, Amy. Syria's Assads turned to West for glossy P.R. New York Times, 10 jun. 2012.

COCKS, Anna Sommer. Syria turmoil kills Mrs Al-Assad's forum. Art Newspaper, 28 abr. 2011.

CHRISAFIS, Angelique. Leading Swiss art broker arrested over alleged price-fixing scam. The Guardian, 26 fev. 2015.

EASTERLING, Keller. Extrastatecraft: The Power of Infrastructure Space. Londres: Verso, 2014.

THE ECONOMIST. Freeports: Über-warehouses for the ultra-rich. 23 nov. 2013. 
ARS FISHER, Max. The only remaining online copy of Vogue's Asma al-

FISHER, Max. Syrian hackers claim AP hack that tipped stock market by $\$ 136$ billion. Is it terrorism?. Washington Post, 23 abr. 2013.

HARRIS, Shane. How did Syria's hacker army suddenly get so good?. Foreign Policy, 4 set. 2013.

KEATING, Joshua. WikiLeaks to move to Sealand?. Foreign Policy, 1 fev. 2012.

MAURISSE, Marie. La 'caverne d'Ali Baba' de Genève, plus grand port franc du monde, ignore la crise. Le Figaro, 20 set. 2014.

NEBEHAY, Stephanie; FRIBAULT, Vincent. Gaddafi son used his paintings to promote Libyan culture. Reuters, 28 out. 2011.

O'MURCHU, Cynthia. Swiss businessman arrested in art market probe. Financial Times, 26 fev. 2015.

OSBORNE, Peter. Anywhere or Not at All: Philosophy of Contemporary Art. Londres: Verso, 2013.

PRYSTAY, Cris. Singapore bling. Wall Street Journal, 21 mai. 2010.

RAVID, Barak. Bashar Assad emails leaked, tips for ABC interview revealed. Haaretz, 7 fev. 2012.

RUSHTON, Suzie. The shape of things to come: Rem Koolhaas's striking designs. The Independent, 21 jun. 2010.

SAIGOL, Lina. The first lady struggles to keep promises. Financial Times, 9 jun. 2011.

SEGAL, David. Swiss free-ports are a home or growing treasury of art. New York Times, 21 jul. 2012. 
SCOTT-RAILTON, John; MARQUIS-BOIRE, Morgan. A call to harm: new malware attacks target the Syrian opposition. Citizen Lab, 21 jun. 2013. Disponível em: citizenlab.org. Acesso em: 23 ago. 2020.

SHAMSEDDINE, Ali; RICH, John. An Introduction to the New Syrian National Archive. e-flux journal, nº 60, dez. 2014.

SLY, Liz. Exodus from the montain: Yazidis flood into Iraq following U.S. airstrikes. Washington Post, 10 ago. 2014.

STONE, Michael. Anonymous supplies WikiLeaks with 'Syria Files'. The Examiner, 9 jul. 2012.

STUART, Hunter. Syrian electronic army denies being attacked by anonymous. Huffington Post, 4 set. 2013.

LE TEMPS. Monaco: Yves Bouvier, le roi des ports francs en garde à vue. Lausana. 26 fev. 2015a

LE TEMPS. Yves Bouvier: les dessous de la plainte. Lausana. 1 de mar. $2015 b$.

TREANOR, Jill. HSBC Swiss bank searched as officials launch moneylaundering inquiry. The Guardian, 18 fev. 2015.

\section{Hito Steyerl}

Hito Steyerl: três capítulos de Arte "Duty Free":

Arte na Era da Guerra Civil

Planetária 


\section{Capítulo 11: A internet está morta?}

ano 18

Tradução: Carolina Eiras Pinto Revisão: Cristina Ambrosio e Lucas Naganuma

Carolina Eiras Pinto

(D) 0000-0001-5196-8335 Cristina Ambrosio

(D) 0000-0002-9822-5712 Lucas Naganuma

(D0000-0001-7952-4613

1. Isso é o que o termo "pós-internet", cunhado alguns anos atrás por Marisa

Olson e, posteriormente, por Gene McHugh, parecia sugerir enquanto tinha um inegável valor de uso, em contraste com o cada vez mais privatizado valor de troca que the coube neste momento.

2. No original: "The internet is probably not dead. It has rather gone all-out. Or more precisely: it is all over!", um trocadilho que não pôde ser traduzido. [N.T.]

3. Cf. WEIBEL (1990).

4. Ceci Moss e Tim Steer em maravilhoso pronunciamento em uma exposição: "0 objeto que se encontra em movimento toca em diferentes pontos, relações e existências, mas sempre se mantém o mesmo. Como o arquivo digital, a cópia pirateada, o ícone, ou Capital, ele reproduz, viaja e acelera, em uma busca constante por suportes que facilitem sua movimentação. À medida que ocupa esses

\section{A internet está morta?}

A internet está morta ${ }^{1}$ ? Não é uma pergunta metafórica. Não sugere que a internet seja disfuncional, inútil ou esteja fora de moda. Ela questiona o que aconteceu com a internet depois que deixou de ser uma possibilidade. A pergunta é bastante literal: se está morta, quando morreu e quem a matou.

Mas como poderia qualquer um considerar que está acabada? A internet está mais potente do que nunca. Não só estimulou, mas conquistou, completamente, a imaginação, atenção e produtividade de mais pessoas do que em qualquer outro momento. Nunca antes houve tantas pessoas mergulhadas na internet, tornando-se dependentes dela e sendo por ela exploradas e supervisionadas. Parece angustiante, deslumbrante, incomparável. A internet provavelmente não está morta. Ao invés disso, se esgotou - mas está por toda parte²!

Isso implica uma dimensão espacial, mas não do jeito que se poderia pensar. A internet não está em todo lugar. Até mesmo hoje em dia, quando a rede parece se proliferar exponencialmente, muitas pessoas não têm acesso à internet ou nem a usam. Ainda assim, está se expandindo, em outra direção. Começa a se deslocar para o offline. Mas como isso funciona?

Lembra a Revolução Romena de 1989, quando manifestantes invadiram os estúdios de TV para fazer história? Naquele momento, as imagens mudaram de função ${ }^{3}$. As transmissões dos estúdios se tornaram catalisadoras dos eventos - e não documentos ou gravações (GHEORGHE, 2012). Desde então, ficou claro que imagens não são, objetiva ou subjetivamente, reféns de uma condição preexistente, nem que funcionam como mera aparência. Elas são, mais precisamente, aglomerados de energia e matéria que migram por diferentes suportes, moldando e afetando pessoas, cenários, a política e sistemas sociais ${ }^{4}$. Elas adquiriram uma habilidade incomum de proliferação, transformação e ativação. Por volta de 1989, imagens televisivas começaram a atravessar as telas diretamente para a realidade ${ }^{5}$.

Esse desenvolvimento se acelerou quando a estrutura da web começou a atuar, junto com as emissoras de TV, como circuitos de imagem ${ }^{6}$. Subitamente, o grau de transmissão se multiplicou. As telas se tornaram onipresentes, sem falar nas próprias imagens, que podiam 
ser compartilhadas com um só clique. Agora, dados, sons e imagens transitam sistematicamente entre telas para um novo estado de matéria ${ }^{7}$. Eles atravessam as fronteiras dos canais de dados e se manifestam materialmente. Eles se encarnam em protestos ou produtos, reflexos de lente, arranha-céus ou tanques pixelados. As imagens se desconectam, tornam-se instáveis, mutáveis, começam a ocupar aquilo que está fora da tela. Invadem cidades, transformando espaços em sites, o real em virtual. Elas se materializam em junkspace, invasões militares e cirurgias plásticas malfeitas. Elas se propagam pela rede e para além da rede, se contraem e se expandem, titubeiam, tropeçam, se agitam, vêm e vão.

É só observar: ilhas artificiais mimetizam plantas manipuladas geneticamente. Consultórios de odontologia servem de cenário para comerciais de carros. Maçãs do rosto são retocadas na mesma medida que cidades inteiras fingem ser tutoriais de AutoCAD no YouTube. Trabalhos de arte são encaminhados por e-mail para aparecerem como pop-ups em halls de bancos projetados em softwares de aviões de caça. Nuvens de armazenagem de arquivos digitais precipitam como chuva no horizonte dos desertos. Ao se tornarem reais, as imagens se alteram substancialmente. São traduzidas, se deturpam, se reconfiguram. Elas se reorientam, mudando de perspectiva e de companhia. Um stories de uma sessão de manicure se torna um cancelamento no Instagram. Um upload errado pode se transformar em uma merda gigantesca. Um GIF se materializa em um portão de aeroporto pop-up. Em alguns casos, é como se sistemas arquitetônicos inteiros da $\mathrm{NSA}^{8}$ fossem construídos mas só depois de passarem pelo Google tradutor, tornando-se galpões de armazenagem de carros de luxo com paredes revestidas de espelhos por dentro e translúcidas para o observador externo. Ao transitarem fora da tela, as imagens são deturpadas, consumidas, incorporadas e remodeladas. Perdem o objetivo, se equivocam com o seu propósito, erram as cores e as formas. Elas atravessam, se desmoronam e então se dissipam novamente para dentro das telas.

"Corporate Cannibal", o videoclipe em preto e branco lançado em 2008 por Grace Jones e descrito por Steven Shaviro como um exemplo primordial da repercussão pós-cinemática, é um caso a se analisar9 Até agora, a descompromissada fluidez e modulação da figura póshumana de Jones tem sido implementada como um modelo para uma infraestrutura austera. Eu poderia jurar que os cronogramas dos ônibus de Berlim se baseiam de modo consistente nesse sistema - dilatando

\section{Hito Steyerl}

Hito Steyerl: três capítulos de Arte "Duty Free":

Arte na Era da Guerra Civil

Planetária

diferentes espaços e formas, está se reconstituindo. Não possui uma existência autônoma, singular; ele é ativado por meio dos links de rede e canais de condução. É, ao mesmo tempo, um processo disperso e um acontecimento único, é como um objeto expandido continuamente circulando, em permanente associação e dispersão. Impedi-lo significaria interromper todo o processo, infraestrutura e correntes que o propagam e reproduzem". Disponível em http://www.seventeengallery. com/. Acesso em: 17 ago. 2020.

5. Um exemplo de um fenômeno político maior chamado de transição. Cunhado por conjunturas políticas na América Latina e depois aplicado ao contexto do Leste Europeu posterior a 1989, esse conceito descreve um processo teleológico que consiste na impossibilidade de sucesso das tentativas

"tardias" de países em alcançar a democracia e a economia de livre-mercado. A transição implica um processo contínuo de metamorfose que, em teoria, faria qualquer lugar finalmente se assemelhar ao sistema ideal da nação ocidental média. Como resultado, regiões inteiras foram submetidas a transformações radicais. Na prática, a transição normalmente se referia a uma desapropriação desenfreada, associada a uma diminuição 
radical na expectativa de vida. Na transição, um futuro neoliberal brilhante marchava para fora das telas para ser executado em forma de carência de assistência médica e falência de contas bancárias, enquanto bancos ocidentais e companhias de seguro não apenas privatizavam aposentadorias, mas as reinvestiam em coleções de arte. Ver WEBER;

KAUFMANN (2006)

6. Imagens migrando entre diferentes suportes não são novidade, claro. Esse processo se evidencia na produção artística desde a idade da pedra, mas a naturalidade com que imagens são transferidas para a terceira dimensão hoje é bem diferente da época em que se traduziam desenhos para esculturas em mármore manualmente. Numa era de pós-produção, praticamente tudo foi criado por meio de uma ou mais imagens, e qualquer mesa das Casas Bahia é copiada e colada ao invés de ser montada ou construída.

7. Como o tumblr New Aesthetic exemplifica, de forma brilhante, com objetos e paisagens (ver https:// newaesthetic.tumblr.com//) e como o tumblr Women as Objects fez para ilustrar a encarnação da imagem como corpo feminino (ver https:// womenasobjects.tumblr. com/l). Igualmente relevante para o assunto é o trabalho de cinema rematerializam-se como ruínas de investimentos ou "Centros de Domínio da Informação” secretos.

Mas, se o cinema irrompeu no mundo para se tornar parcialmente real, é preciso concordar que ele literalmente explodiu. E provavelmente também não sobreviveu à explosão.

\section{Pós-cinema}

Por um bom tempo, muitas pessoas sentiram que o cinema estava um pouco sem vida. Hoje, ele é principalmente um meio para se comprar novos televisores, projetores e iPads. Há muito ele se tornou uma plataforma para a venda de franquias de produtos - exibindo filmes adaptados de versões cada vez mais modernas de jogos de PlayStation em enormes salas assépticas -, tornando-se um dispositivo educacional para o que Thomas Elsaesser chama de complexo de entretenimento bélico-industrial.

Todo mundo tem a sua versão de quando e como o cinema morreu, mas eu, particularmente, acredito que ele foi atingido por um estilhaço quando, durante a Guerra da Bósnia, um pequeno cinema em Jajce foi destruído, por volta de 1993. Esse foi o momento da fundação da República Socialista Federativa da Iugoslávia, durante a Segunda Guerra Mundial, pelo Conselho Antifascista para Liberação Nacional da Iugoslávia. Tenho certeza de que o cinema foi atingido da mesma forma em muitos outros lugares. Foi baleado, sequestrado e executado no Líbano e na Argélia, na Chechênia e na República Democrática do Congo, assim como em outros conflitos pós-Guerra Fria. Ele não só se retirou de cena e se tornou indisponível, como escreveu Jalal Toufic depois do que chamou de catástrofe insuperável (TOUFIC, 2009).

Ele foi assassinado, ou pelo menos entrou em coma permanente.

Mas voltemos à pergunta inicial. Nos últimos anos, muitas pessoas - praticamente todo mundo - notaram que a internet também anda estranha. Obviamente está completamente tomada, monopolizada, desinfetada pelo senso comum, pelos direitos autorais, pelo controle e conformismo. Parece tão vibrante quanto o mais novo cinema de Multiplex da década de 1990 reprisando infinitamente Star Wars: Episódio 1. Teria sido a internet atingida por um sniper na Síria, um drone no Paquistão ou uma granada na Turquia? Estaria hospitalizada 
em Porto Said, com uma bala na cabeça? Cometeu suicídio ao pular da janela de um Centro de Domínio Informacional? Mas não existem janelas nesse tipo de construção. E não existem paredes. A internet não está morta. É um zumbi e está por toda parte.

\section{Eu sou um computador de redstone no Minecraft}

Afinal, o que significa a internet estar offline? Ela ultrapassou a tela, multiplicou displays, transcendeu a rede e os cabos para se encontrar, ao mesmo tempo, inativa e inevitável. É possível imaginar-se desligando todo o acesso online ou atividade de usuário. Nós podemos estar desconectados, mas isso não significa que estamos a salvo. A internet se mantém offline como um modo de vida, de organização, produção e fiscalização - uma forma de voyeurismo intenso associada à máxima não transparência. Imagine uma internet de apáticos "curtindo" uns aos outros, reforçando o regime de alguns quasi monopólios. Um mundo de conhecimento privatizado vigiado e defendido por agências de avaliação. De controle máximo associado a um conformismo intenso, onde carros inteligentes fazem as compras de mercado até o momento em que um míssil da Hellfire atinge o alvo. Oficiais da polícia aparecem na sua porta por causa de um download - e te prendem depois de te identificar no YouTube ou por uma rede de câmeras de vigilância. Vão ameaçar te levar para a cadeia por disseminar conhecimento público? Ou talvez te pedir para derrubar o Twitter para evitar uma insurgência? Aperte suas mãos e os convide para entrar. Eles são a internet em 4D.

A condição de esgotamento da internet não é uma interface, mas um contexto. Outras mídias, assim como a imagem de pessoas, de estruturas e objetos, estão mergulhadas na questão da rede. Espaços conectados já são, em si, uma mídia, ou qualquer nome que queiram dar para esse estado promíscuo, póstumo de uma mídia. É uma forma de vida (e morte) que domina, suprime e arquiva todas as mídias anteriores. Nesse espaço fluido da mídia, sons e imagens se metamorfoseiam para diferentes autoridades e operadoras, adquirindo cada vez mais falhas e anomalias pelo caminho. Além disso, não é apenas a forma que migra pelas telas, mas também a função (METAHAVEN; BRATTON, 2012).

Computação e conectividade intervêm na matéria, renderizando-a como um material bruto para a predição algorítmica, ou potencialmente construindo blocos para redes alternativas. Computadores de redstone
Jesse Darling e Jennifer Chan.

8. National Security Agency, em tradução livre, Agência Nacional de Segurança. [N.T.]

9. Ver a incrível análise de SHAVIRO (2010a) e também seu livro (cf. SHAVIRO, 2010b). 

da mesma forma, material vivo e morto se integram progressivamente ao

10. Agradeço a Josh Crowe por chamar minha atenção para isso; Cf. METAHAVEN; BRATTON (2012)

11. No original: "floaters in a fleeting world of images, interns in dark net soap lands". No vocabulário urbano, darknet, ou dark net, se refere ao "site do demo" (devil's URL), uma parte do espaço IP que não executa nenhum serviço, não possui um host ativo e é, portanto, de difícil rastreamento. Soap lands, ou soaplands, termo importado da cultura japonesa, corresponde a um serviço de casa de banhos. [N.T.]

12. Ver Oliver Laric, Versions (2012). Disponível em: http://oliverlaric.com/ vvversions.htm rendimento da nuvem, lentamente transformando o mundo em uma placamãe multicamadas ${ }^{10}$.

Mas também esse ambiente é uma esfera de liquidez - de clima instável, com iminentes tempestades. É a complexidade fora de controle, se retroalimentando de forma bizarra. Uma condição relativamente construída pelos humanos, mas também apenas em parte controlada por eles, indiferente a tudo exceto ao movimento, à energia, ao ritmo e à desordem. É o lugar dos ronins, dos samurais sem mestre, apropriadamente chamados de mulheres e homens-onda: vagueiam num mar de imagens, vivendo em terras de desabrigados ${ }^{11}$. Pensamos que fosse um sistema encanado, mas então como veio parar esse tsunami na minha pia? Como que esse algoritmo veio parar no meu arroz? Quantos trabalhadores não estão desesperadamente tentando tocar as nuvens que se situam agressivamente no horizonte nesse exato momento, tentando extrair dali um sustento, tateando através de um nevoeiro que pode a qualquer instante se transformar tanto numa instalação de arte imersiva quanto numa mostra de gás lacrimogêneo?

\section{Pós-produção}

Mas se as imagens começaram a inundar o mundo através das telas, invadindo sujeito e objeto material, a maior e mais negligenciada consequência é que a realidade agora consiste efetivamente em imagens; ou, ainda, em coisas, constelações e processos outrora evidentemente imagéticos. Isso significa que não se pode compreender a realidade sem assimilar cinema, fotografia, modelagem $3 \mathrm{D}$, animação e outras formas de imagens cinéticas e estáticas. $\mathrm{O}$ mundo está impregnado pelos estilhaços das imagens brutas, editadas, photoshopadas e restauradas. A própria realidade é roteirizada, pós-produzida e renderizada no After Effects. Longe de serem opostos separados por um abismo intransponível, imagem e mundo são, em diversas ocasiões, somente versões um do outro ${ }^{12}$.

Apesar disso, não são equivalentes. São excessivos e insuficientes, desequilibrados um em relação ao outro. A diferença entre eles dá margem para especulações/reflexões e ansiedades.

Sob essas condições, a produção se metamorfoseia em pós-produção, o que significa que o mundo pode ser não só compreendido, mas também 
modificado por essas ferramentas. As ferramentas da pós-produção: edição, correção de cor, filtros, cortes etc. não são destinadas a alcançar a representação. Elas se tornaram meios de criação - não só de imagens, mas do mundo em seu despertar. Uma possível razão: com a proliferação digital de todo tipo de imagem, subitamente o mundo se tornou disponível. Citando a famosa fábula de Borges (1999a), o mapa não só se tornou semelhante ao mundo como, agora, o supera ${ }^{13}$.

Uma vasta parcela de imagens cobre a superfície do mundo literalmente, no caso da imagem aérea - numa confusa acumulação de camadas. $\mathrm{O}$ mapa irrompe em um território material, que progressivamente se fragmenta e a ele se emaranha: por exemplo, a cartografia do Google Maps quase desencadeou um conflito militar ${ }^{14}$. Enquanto Borges apostou que o mapa se extinguiria, Baudrillard (1988) especulou que, ao contrário, a realidade estava se desintegrando.

De fato, ambos se difundem e confundem um ao outro: em dispositivos portáteis, checkpoints e entre uma versão editada e outra. Mapa e território aproximam-se um do outro, fazendo do arrastar de dedos em um touchpad um parque temático ou edificações de apartheid. Camadas de imagem ficam presas tal como sedimentos geológicos, enquanto equipes da $\mathrm{SWAT}^{15}$ patrulham carrinhos de compra da Amazon. O ponto é que ninguém consegue lidar com isso. Essa bagunça, essa zona imensa e exaustiva precisa ser reformulada em tempo real: editada, filtrada, escaneada, classificada e ordenada - em inúmeras páginas da Wikipédia, em geografias logísticas, distorcidas, libidinais, categorizadas.

Isso atribui um novo papel para a produção de imagem e, como consequência, também para as pessoas que trabalham nessa área. Produtores de imagem agora atuam diretamente em um mundo feito de imagens e podem fazê-lo de modo muito mais rápido do que o que era possível no passado. Mas a produção também se fundiu à circulação, ao ponto de se tornarem indistinguíveis. A fábrica/ateliê/Tumblr se mescla com compras online, marcas oligárquicas, promoções de imóveis e arquitetura de vigilância. Hoje, o ambiente de trabalho pode se revelar como um algoritmo nocivo comandando seu disco rígido, sua visão e seus sonhos. E amanhã você pode ter que dançar todo o caminho em direção à insanidade.

Conforme a web escorre para uma outra dimensão, a produção de imagem se move para muito além de setores especializados. Ela se transforma em pós-produção de massa, em uma era de concorrência criativa. Hoje, praticamente todo mundo é um artista. Estamos a todo momento
296

Hito Steyerl

Hito Steyerl: três capítulos de Arte "Duty Free":

Arte na Era da Guerra Civil

Planetária

13. “'Naquele Império, a Arte da Cartografia logrou tal perfeição que o mapa de uma única Província ocupava toda uma Cidade, e o mapa do império, toda uma Província. Com o tempo, esses Mapas Desmedidos não satisfizeram e os Colégios de Cartógrafos levantaram um Mapa do Império, que tinha o tamanho do Império e coincidia pontualmente com ele. Menos Adictas ao Estudo da Cartografia, as Gerações Seguintes entenderam que esse dilatado Mapa era Inútil e não sem Impiedade o entregaram às Inclemências do Sol e dos Invernos. Nos desertos do Oeste perduram despedaçadas Ruínas do Mapa, habitadas por Animais e por Mendigos; em todo o País não há outra relíquia das Disciplinas Cartográficas'. Suárez Miranda, Viajes de Varones Prudentes, livro quarto, capítulo XLV, Lérida, 1658." (BORGES, 1999b, p. 247)

14. ARIAS (2013). Agradeço a Kevan Jenson por mencionar isso pra mim.

15. Special Weapons and Tactics, em tradução livre, Armas e Táticas Especiais, uma unidade de polícia altamente especializada. [N.T.] 

compartilhando correntes e praticando mansplaining. A todo momento

16. No original: "We are pitching, phishing, spamming, chain-liking or mansplaining. We are twitching, tweeting, and toasting as some form of solo relational art, high on dual processing and

a smartphone flat rate".

0 termo "pitch" pode ser traduzido literalmente como "arremessar", "lançar", "armar", no contexto esportivo, mas também se refere a uma apresentação de três a cinco minutos, uma sumarização para vendas. "Phishing" ou "catfishing", cuja origem encontra-se em fishing (do inglês "pescar"), refere-se a quando um scammer ou hacker tenta

fingir ser uma pessoa ou organização legítima com o intuito de roubar informações.

"Spamming", mandar spam, consiste no envio de mensagens não autorizadas.

"Mansplaining"é usado para descrever quando um homem tenta explicar algo para uma mulher, assumindo que ela não entende do assunto. "Chain-linking"é gíria para descrever uma posição sexual em que dois homens se penetram mutuamente; "chain-liking", por sua vez, pode estar se referindo a uma situação de bajulação,

ou a quando se cria uma corrente de likes, de curtidas ou compartilhamentos, mantendo a insinuação sexual. "Ttwitching", tradução literal para "espasmos", tremores, é gíria para espiar, quase um voyeurismo. twittando, cancelando alguém ou stalkeando como forma de criar algum tipo de arte autônoma relacional com uma fixação em smartphones ${ }^{16}$. A circulação da imagem nos dias de hoje funciona pelo lenocínio de pixels em rede via compartilhamento estratégico de conteúdo excêntrico, neotribal e majoritariamente estadunidense. Objetos duvidosos, GIFs de gatinhos e uma miscelânea de imagens anônimas se proliferam por nossos corpos via WiFi. Alguém poderia talvez interpretar os resultados como uma nova e vital forma de arte popular, isto é, se esse alguém estiver preparado para reformular completamente suas definições de "popular" e de "arte". Uma nova forma de contar histórias, que usa emojis e tweets com ameaça de estupro, está criando e ao mesmo tempo destruindo comunidades ligadas pelo déficit de atenção que têm em comum.

\section{Circulacionismo}

Essas coisas não são tão novas quanto parecem. O que a vanguarda soviética do século XX chamou de produtivismo-a reivindicação de que a arte deveria penetrar a produção e a indústria - poderia agora ser substituída pelo circulacionismo. Circulacionismo não é sobre a arte de fazer uma imagem, mas sobre pós-produzi-la, acelerá-la, difundi-la. É sobre as relações públicas das imagens através das redes sociais, sobre publicidade \& propaganda e alienação, sobre um ócio tão suave, débil e lento quanto possível.

Lembra como os produtivistas Maiakovski e Rodchenko criaram outdoors para $\mathrm{NEP}^{17}$ ? Comunistas engajados com entusiasmo ao fetichismo da mercadoria (KIAER, 2010) ${ }^{18}$ ?

Fundamentalmente, o circulacionismo, se reinventado, poderia compreender redes de curto-circuito, contornando e ignorando amizades corporativas e monopólios de hardware. Poderia se tornar a arte de recodificar ou reescrever sistemas ao expor a escopofilia do estado, conformidade/ submissão com o capital e vigilância indiscriminada. Lógico que ele pode dar tão errado quanto seu predecessor, ao alinhar-se a um culto stalinista da produtividade, intensificação e exaustão heróica. O produtivismo histórico foi - vamos encarar os fatos - completamente ineficaz, sendo derrotado desde cedo por um esmagador aparato burocrático de monitoramento/ workfare. É muito provável que o circulacionismo - ao invés de reestruturar 
a circulação - torne-se um ornamento para uma internet que se parece cada vez mais com um shopping repleto de franquias da Starbucks geridas por Joseph Stalin.

Será que o circulacionismo terá a capacidade de alterar o hardware e software da realidade - suas causas, drivers e processadores ${ }^{19}$ ? Enquanto o produtivismo deixou poucos rastros em uma ditadura sustentada pelo culto ao trabalho, poderia o circulacionismo mudar uma condição em que a visão, insônia e exposição são fábricas de algoritmos? Estariam stakhanovistas circulacionistas trabalhando em fazendas em Bangladesh, ou minerando ouro virtual em campos de concentração chineses, revirando conteúdo corporativo em transportadoras digitais ${ }^{20}$ ?

\section{Acesso livre}

Mas aqui está a derradeira consequência da internet ter se desconectado ${ }^{21}$. Se imagens podem ser compartilhadas, por que todo o resto não pode também? Se dados se movem para além das telas, então também pode o seu material encarnado mover-se para além de vitrines das lojas e outros invólucros. Se os direitos autorais podem ser driblados e postos em questão, por que não poderia a propriedade privada? Se alguém pode compartilhar um JPEG de um prato de restaurante no Facebook, por que não poderia também a refeição verdadeira? Por que não aplicar uma utilização legítima para o espaço, para parques e piscinas ${ }^{22}$ ? Por que reivindicar acesso livre para o JSTOR e não ao MIT - ou qualquer outra universidade, escola ou hospital, nesse sentido? Por que as nuvens de dados não poderiam precipitar como arrastões em supermercados ${ }^{23}$ ?

Por que não água, energia e champanhe open source?

Se circulacionismo significa alguma coisa, precisa se mobilizar para um mundo de distribuição offline, de disseminação de recursos 3D, de compartilhamento de terras, música e inspiração. Por que não se retirar lentamente de uma internet zumbi para construir algumas outras paralelas?

\section{Hito Steyerl}

Hito Steyerl: três capítulos de Arte "Duty Free":

Arte na Era da Guerra Civil

Planetária

"Ttweeting", twittar, é o uso da rede social Twitter. 0 termo "toasting"tem como tradução literal "torrar", é uma gíria para descrever uma situação de humilhação na internet, relaciona-se com termos como "destroyed"e "ruined", literalmente "destruição", "ruína". [N.T.]

17. National Energy Policy, em tradução livre, Política Nacional de Energia. [N.T.]

18. "Os toques de publicidade de Maiakovski são direcionados diretamente aos consumidores da classe trabalhadora soviética, sem ironias; por exemplo, em um anúncio da Mosselprom, o voto de confiança do estado para a agricultura, se lê: 'Óleo de cozinha. Atenção, trabalhadores! Três vezes mais barato do que manteiga!

Mais nutritivo do que qualquer outro óleo! Você só encontra na Mosselprom'. Não surpreende que a publicidade construtivista falaria em uma linguagem próBolchevique anti-empresasNEP, mas a imagem da campanha de negócios da Reklam-Konstruktor é mais complicada do que isso. Muitas de suas ilustrações comerciais avançam para além dessa linguagem direta de diferenças de classe e necessidades utilitárias, oferecendo uma teoria do objeto socialista. Em contraste com as reivindicações de Brik, de que nesse tipo de 

Times, 20 set. 2013.

produção eles estão apenas

'leiloando seu tempo', eu proponho que seus comerciais tentam trabalhar a relação entre a cultura material de um passado pré-revolucionário,

o presente NEP e o futuro socialista de Novy Byt com um rigor teórico. Confrontam o questionamento que emerge da teoria de Boris Arvatov: 0 que acontece com as fantasias e desejos individuais estruturados no capitalismo pelo fetichismo da mercadoria - e com o mercado, depois da revolução?" (Tradução minha).

[N.T.]

19. No original: "[...] its affects, drives, and processes?", um trocadilho com peças de computador que não pôde ser traduzido. [N.T]

20. Cf. ARTHUR (2013), SANDERSON (2013).

21. E claro que não está presa a esculturas provenientes de arquivos digitais e expostas em galerias do cubo branco.

22. "Trabalhadores espanhóis ocupam propriedade de duque e a transformam em fazenda",

24 ago. 2012. Disponível em: https://libcom.org/blog/ spanish-workers-occupyduke's-estate-turn-itfarm-24082012. Acesso em:

17 ago. 2020. "Nesta semana, em Andaluzia, centenas de trabalhadores agrícolas desempregados invadiram a cerca que marcava uma propriedade pertencente
ARTHUR, Charles. How low-paid workers at 'click farms' create appearance of online popularity. The Guardian, 2 ago. 2013.

BAUDRILLARD, Jean. Simulacra and Simulations. In: POSTER, Mark. Jean Baudrillard: Selected Writings. Stanford: Stanford University Press, 1988, pp.166-184.

BORGES, Jorge Luís. On Exactitude in Science. In Collected Fictions / trad. Andrew Hurley. Nova lorque: Penguin, 1999, pp.75-82.

BORGES, Jorge Luis. Obras Completas (1952-1972). Editora Globo: São Paulo, 1999b. v.2.

GHEORGHE, Cãtãlin. The Juridical Rewriting of History. In: GHEORGHE, Cãtãlin (ed). Trial/Proces. Iaşi: Universidade Nacional de Arte George Enescu, 2012, pp. 2-4.

KIAER, Christina. 'Into Production!': The Socialist Objects of Russian Constructivism. Transversal, set. 2010.

METAHAVEN; BRATTON, Benjamin. The Cloud, the State, and the Stack: Metahaven in Conversation with Benjamin Bratton. 16 dez. 2012. Disponível em: https://mthvn.tumblr.com/post/38098461078/ thecloudthestateandthestack. Acesso em: 17 ago. 2020.

SANDERSON, Harry. Human Resolution. Mute, 4 abril 2013.

SHAVIRO, Steven. Post-Cinematic Affect: On Grace Jones, Boarding Gate and Southland Tales. Film-Philosophy, 14(1), 2010a, pp.1-102.

SHAVIRO, Steven. Post-Cinematic Affect. Londres: Zero Books, 2010b.

TOUFIC, Jalal. The Withdrawal of Tradition Past a Surpassing Catastrophe. 
Hito Steyerl

Hito Steyerl: três capítulos de Arte "Duty Free":

Arte na Era da Guerra Civil Planetária
WEIBEL, Peter. Medien als Maske: Videokratie. In: SEI, Keiko (ed.). Von der Bürokratie zur Telekratie. Rumänien im Fernsehen. Berlim: Merve, 1990, pp.124-149. ao Duque de Segorbe, reivindicando-a como deles. Essa foi a mais recente de uma série de ocupações que ocorreram na região no último mês. Seu objetivo é desenvolver um projeto de agricultura comunitária, similar ao de outras fazendas ocupadas, a fim de trazer novos ares para uma região que vem enfrentando uma taxa de desemprego de mais de $40 \%$. Direcionandose aos ocupantes, Diego Canamero, membro da União de Trabalhadores de Andaluzia, disse: 'Estamos aqui para denunciar uma classe social que desperdiça estas terras'. Os luxuriosos e bem-conservados jardins, casa e piscina foram deixados desocupados, já que o Duque mora em Sevilha, a mais de 90 quilômetros de distância".

23. "Prefeito da Espanha lidera saques para o povo". 25 de agosto de 2012 .

Disponível em: https://www. workers.org/2012/08/3561/. Acesso em: 17 ago. 2020. “No pequeno município de Marinaleda, na Espanha, localizada na região sul de Andaluzia, o prefeito Juan Manuel Sánchez Gordillo encontrou uma solução para a crise econômica do país e a fome que assola a região: ele organizou e liderou pilhagens aos supermercados para seus cidadãos buscarem a comida necessária para sobrevivência". 


\section{Capítulo 13: Vamos falar de fascismo}

ano 18

ก. 39

Tradução: Janaina Wagner e

Gabriel Ussami

Revisão: Pedro Andrada

Janaina Wagner (D) 0000-0003-2081-6560

Gabriel Ussami

(D) 0000-0003-3535-8830

Pedro Andrada

(D) $0000-0002-4145-9745$
Sim, eu estou falando sério. Não vamos falar sobre psicologia ou sobre o mal em si. Não vamos falar de insanidade ou de uma repentina e imprevisível desgraça. Você está tentando evitar o tópico. O tópico é o fascismo.

Vimos um esquivamento similar após os ataques em Oslo e em Utøya. Como se as sociedades não quisessem confiar em seus próprios olhos e ouvidos. $\mathrm{O}$ autor dos ataques articulou abertamente suas crenças neofascistas. Ainda assim, as pessoas estão tentando evitar esse fato. Seu ato não é chamado de ato de terror, mas de lunatismo. Ele é despolitizado e representado como um desvio privado que inesperadamente atinge o país como um desastre natural. É divorciado da sua dimensão política e se torna uma ação privada, individual.

Porém, essa esquiva tem algo a mais para nos contar. Ela aponta para uma lacuna na representação em si. Origina-se de questões epistemológicas e políticas muito sérias, que são trabalhadas profundamente no tecido do fascismo contemporâneo e em seu ressurgimento na Europa afora e além. Mais do que isso: elas estão fundamentalmente enraizadas nas maneiras pelas quais percebemos a realidade contemporânea.

No entanto, o problema central não é a falta de moralidade. Tampouco é uma questão de bom ou mau, sanidade ou enfermidade. É uma questão da representação. De um lado, representação política, do outro, representação cultural. E, na verdade, em terceiro lugar, de participação econômica. E o que tudo isso tem a ver com as reações públicas ao massacre?

\section{Representação política}

Afinal, o que são representação política e representação cultural? Mais precisamente: quais são as disparidades existentes "dentro" desses conceitos e entre eles? Eles repousam sobre contradições que são irresolúveis, e o fascismo parece um conveniente jump cut em uma tentativa de explodir essas diferentes aporias.

Vamos começar pelo básico. A representação política em uma democracia liberal é obtida principalmente através da participação no processo eleitoral. Isto requer cidadania. Uma verdadeira representação política é, portanto, inadequada em todas as democracias europeias. 
Isso é bem sabido. Mas agora existem questões muito mais gerais e urgentes. O poder político está sendo progressivamente erodido. Quem alcança ou não alcança representação política importa cada vez menos. Até mesmo pessoas com privilégios políticos totais, membros de partidos - até mesmo Hito Steyerl: três capítulos de Arte "Duty Free":

Arte na Era da Guerra Civil

Planetária parlamentares - são ignorados mais e mais. Porque, não importa o que querem as pessoas, quem elas são e, independentemente de quem as representa, os soberanos contemporâneos são principalmente os "mercados". Os mercados, e não as pessoas, devem ser apaziguados, satisfeitos e agradados pela classe política. Na área da economia, a representação também existe. A participação nos processos econômicos é medida pelas habilidades para obter crédito, possuir e consumir. Isso também explica a ira contemporânea contra o que é essencialmente econômico ou contra a exclusão do consumidor. Muitos protestos contemporâneos não possuem objetivos políticos - e por que deveriam, uma vez que a ação política se mostra impotente em tantos casos? -, mas brigam pela participação econômica: a expressão mais concentrada disso é a pilhagem de shopping centers.

Essa erosão do poder político é o resultado de décadas da redistribuição de oportunidade, riqueza e poder real do pobre para o rico. Enquanto isso foi possível, os pobres foram satisfeitos com crédito e poder de compra. Agora que isso não parece mais funcionar, a participação econômica se tornou um campo de batalha.

Mas o que é que tudo isso tem a ver com fascismo? Na superfície, nada. Mas esses fenômenos são todos sintomas daquilo que poderia provisoriamente ser chamado de pós-democracia. Na pós-democracia, a política é sucessivamente abandonada como um meio de organizar o comum.

A pós-democracia também é sentida nas instituições políticas. Cidadãos da União Europeia, por exemplo, são confrontados com uma série de instituições que não são legitimadas democraticamente (entre essas, novamente, instituições financeiras, que não estão sujeitas a nenhum controle político). Dependendo de sua cidadania, os votos dos cidadãos não têm o mesmo peso, criando assim diferentes classes de representação política. Dentro e fora da Europa, oligarquias de todos os tipos estão em ascensão. Burocracias partem em retirada e são substituídas por regimes autoritários, agitações tribais e vigilância organizada. O denominado monopólio da violência é cada vez mais privatizado, entregue de bandeja a exércitos privados, empresas de segurança e gangues terceirizadas. Forças que poderiam ser controladas democraticamente estão se enfraquecendo, enquanto estados e outros atores impõem suas agendas por meio de poderes 
emergenciais ou da "necessidade". Tem havido tantos exemplos disso

1. Por exemplo, KARATANI (2003, p. 151).

2. Proxy é um servidor que age em redes de computadores como um intermediário para requisições de clientes, solicitando recursos de outros servidores.

3. Gayatri Spivak é crítica e teórica, mais conhecida por seu artigo "Pode o Subalterno

Falar?", texto sobre o póscolonialismo considerado fundamental.

4. Antonio Gramsci foi um filósofo marxista, jornalista, crítico literário e político italiano. Escreveu sobre teoria política, sociologia, antropologia e linguística. durante as últimas décadas que não quero nem começar a listá-los.

Todos esses sintomas intensificam ansiedades em torno da ideia de representação política como tal. Não nos foi prometida igualdade? Sim, nos foi. A ideia de democracia não era aquela em que todos nós seríamos representados? Não, nós não somos. Representação política envolve certa arbitrariedade e aleatoriedade - até determinado ponto, inerentes a ela, mas que agora parecem estar sendo aceleradas em um ritmo tremendo ${ }^{1}$. Envolve instabilidade, imprevisibilidade e uma grande dose de futilidade.

\section{Representação cultural}

E a representação cultural, então, como fica? O que é isso, afinal? Representação cultural é (em muitos casos, visual) a representação na esfera pública. Via textos, anúncios, cultura popular, televisão - o que você quiser. Não precisamos entrar nessas, você só precisa olhar ao seu redor. A situação parece ser bem diferente por aqui. Existe uma superabundância de representação de quase tudo e todos: tanto nas mídias comerciais quanto nas sociais. Essa avalanche de representação aumentou muito com as tecnologias digitais. No entanto, o fato de coisas e pessoas serem representadas culturalmente não significa muito. Significa apenas que montes de imagens estão flutuando por aí, se acotovelando por atenção.

Qual é, então, a relação entre representação política e representação cultural? Entre Darstellung e Vertretung, ou entre proxy ${ }^{2}$ e retrato, como Gayatri Spivak ${ }^{3}$ colocou?

Existe uma. Mas não é aquela que tradicionalmente se supõem existir. Cerca de trinta a quarenta anos atrás, no seu início, os Estudos Culturais, com suas implicações gramscianas ${ }^{4}$, entendiam a representação cultural como uma espécie de democracia visual. A suposição era mais ou menos assim: se as pessoas fossem representadas culturalmente de maneira positiva, a igualdade política se tornaria mais provável. Batalhas apaixonadas acerca da ideia de uma política de representação caracterizaram grande parte dos anos 1980 (e, em muitos lugares, de outros períodos bem além dessa década).

Mas agora nós estamos percebendo que algo nessa equação deu errado; ou, para colocar em termos mais neutros, que algo mudou dramaticamente. Enquanto a representação cultural de tudo está passando 
por uma inflação massiva (pareada com a desvalorização e degradação da maioria das imagens, textos e sons individuais), a representação política não apenas está desigual, mas também cada vez menos relevante. Os dois domínios também parecem estar descontroladamente fora de sincronia. O período de crescimento exponencial de todas as coisas representadas, a era da proliferação de imagens e dados em circulação é também o período de radicalização das políticas anti-imigração, da instituição de regimes fronteiriços cada vez mais severos, do crescimento de neofascistas (alguns preferem chamá-los de movimentos e partidos populistas de direita) e de uma perda geral da autoridade da política.

Se alguém insistisse nisso, poderia concluir que existe uma relação quase inversamente proporcional entre representação política e cultural. Quanto mais as pessoas são representadas culturalmente, e quanto mais elas capturam umas às outras em seus celulares e se submetem aos esquemas de vigilância do Facebook, menos elas importam politicamente. Mas esse pode ser o caso apenas parcialmente. O link real talvez seja que ambos os tipos funcionem perfeitamente de maneira errática e desigual. Ambos são mais retratos do que proxys, e não necessariamente retratos muito bons.

\section{0 colapso da representação}

E, agora, a recusa em reconhecer o fascismo, ainda que ele seja proclamado publicamente e sustentado por atrocidades, como no caso dos ataques em Oslo e Utøya, fica mais clara - porque essa esquiva aponta para um ponto cego que conecta o problema da representação ao fascismo.

Por que é assim? Porque no fascismo a representação colapsa. Ele é curto-circuitado por tentativas de evitar todas as complicações inerentes a ele e de rotular a representação como um conceito estranho e estrangeiro. $\mathrm{O}$ fascismo alega expressar a essência do povo, impondo um líder e substituindo a representação cultural por caricaturas dissimuladas de simples verdade. Ele tenta se livrar da representação de forma geral.

E, de fato, existem muitas razões para se desconfiar da representação contemporânea. Tanto na representação política quanto na cultural, o vínculo entre representado e representação parece ter se tornado dramaticamente mais complicado nos últimos anos e, muitas vezes, ele se desintegra completamente. A representação, como nós 
a conhecemos, está caminhando para um desastre - ou então está

ano 18

n. 39

5. No original, a autora utiliza "slippage". Este é um termo usado dentro do mercado financeiro para definir quando uma compra, ou venda, de uma mercadoria é feita por um preço diferente do que havia sido acordado formalmente. Isso ocorre devido ao intervalo de tempo entre a flutuação do valor e de seu reconhecimento pelos “livros de ofertas", isto é, na efetivação real da negociação.

Mesmo no Brasil, o termo é correntemente empregado em inglês, sem tradução. No texto, traduzimos por "deslize", pois o uso que a autora faz remete tanto ao sentido literal da palavra quanto à utilização do vocabulário no mercado financeiro. mergulhando de cabeça em uma vertiginosa espiral.

Na representação cultural, o conceito de realidade foi tensionado de modo sem precedentes. Muitas das regras e convenções da representação visual tornaram-se quase obsoletas com a recente revolução digital. No caso das imagens, o chamado vínculo indexical da fotografia (que sempre foi duvidoso) foi destruído por tecnologias de copiar e colar, por campanhas que parecem cortina de fumaça e por oportunidades inéditas de fraudes, desinformação e trapaça. Os procedimentos tradicionais de verificação da verdade - jornalísticos, jurídicos e, em certa medida, também científicos foram substituídos por boatos digitais, desregulamentação generalizada, lei da demanda e fontes de "conhecimento" coletivo semelhantes à Wikipedia. Claramente, representação cultural sempre foi algo capcioso. Mas a emergência do fascismo 2.0 fala com um momento em que o rancor digital pode se espalhar como um incêndio selvagem, alimentado por avatares dificilmente capazes de ainda se conectar a pessoas reais. Assim como a representação em si foi desatada de seu controle institucional, o seu conteúdo tem sido, em muitos casos, divorciado de qualquer realidade empírica. Não me interprete mal. Não acho que a revolução digital seja algo ruim. Ao contrário, ela permitiu muitos avanços importantes na livre circulação de informações. Mas isso às custas de maior incerteza e instabilidade. Não há como negar isso também.

$\mathrm{Na}$ representação política, um dos principais acontecimentos dos últimos anos é que mesmo aqueles que são representados politicamente sentem-se impotentes, uma vez que o poder, hoje, parece estar codificado de forma mais econômica do que política. Então, ironicamente, representação política começa a se parecer com representação cultural. Torna-se mais retrato do que proxy, enquanto suas contradições internas aumentam. Assim, as complicações se intensificam em ambas as representações, política e cultural.

\section{Finanças e epistemologia}

Talvez o denominador comum de toda a diversidade de deslizes ${ }^{5}$ nas representações seja a noção de especulação. Especulação é, primeiramente, uma ferramenta financeira e epistemológica. Nas finanças, especulação significa dar um passo cujas implicações não podem ser previstas de forma 
segura. Nem todas as informações estão (ou podem estar) disponíveis no momento da tomada de decisão. Portanto, o risco é elevado, mas, presumidamente, também a oportunidade. Especulação também significa que o valor está cada vez mais desvinculado de seu objeto referente. Já não se refere à "coisa" em questão, mas a seu contexto de circulação e os efeitos ligados a ele. Ela representa oscilações de humor em torno dos derivativos de derivativos. É mais como o feedback de vídeo filmado por uma câmera de mão descontroladamente agitada do que uma ilustração convencional (e por isso eu não pretendo indicar que o último é mais confiável que o primeiro somente mais previsível).

Não é difícil ver como isso se relaciona com a especulação enquanto um instrumento de observação e pesquisa. Speculari significa observar em Latim. É usado como a tradução em Latim do Grego theoria e descreve a procura pela essência, ou origem, das coisas por trás de sua existência empírica. Ao mesmo tempo, refere-se a um mergulho na névoa da pura aparência, como as reflexões de Santo Agostinho acerca do reconhecimento de Deus no espelho sombrio sugerem. Segundo Hans Reichenbach, a especulação caracteriza períodos de transição na filosofia, quando as questões colocadas excedem os próprios meios racionais possíveis para respondê-las. Assim, a especulação filosófica também apresenta riscos e oportunidades. Expõe a possibilidade de pensar fora da caixa, assim como o perigo de ficar completamente perdido por aí.

Mas especulação veio também para caracterizar muitos processos vernaculares de representação. Todas as coisas que não são conhecidas, mas são suspeitas. Todos os rumores que não são fundamentados. Toda a complexidade comprimida além do reconhecimento. Vídeo virais, cuja circulação é multiplicada em bolhas de representação, com uma espessa camada de efeito pingando delas. Cinzentas, abstratas cenas de zonas de guerra. $\mathrm{O}$ vício na emergência, na catástrofe e suas subsequentes inflações em telas exponencialmente multiplicadas. A perda da confiança em imagens e em qualquer outro valor referencial e sua relação com tudo a que eles se referem.

Muitos dos processos que caracterizam a especulação em geral acima de tudo seu risco e relação dessubstancializada com a realidade - são inerentes às práticas de representação digital. A representação em si é extremamente dinamizada pela especulação. O resultado é que a relação entre o referente e o signo, e entre uma pessoa e a proxy, tornase intensamente imprevisíveis - assim como diversos outros fenômenos 
contemporâneos. A especulação turbina a representação; ela acelera o

ano 18

ก. 39 movimento em parafuso que vivemos hoje.

Isso não é apenas má notícia. A especulação como método torna acessível novas liberdades de expressão e pensamento, que, por outro lado, podem ser facilmente utilizadas de maneira terrível. Oportunidades surgem a todo minuto - e realidades são desperdiçadas e destruídas ao mesmo tempo. Isso permite um novo horizonte de pensamento, que, em muitos casos, acaba em desilusões completas. Especulação é o prenúncio da possibilidade e da exploração, assim como se traduz em intolerância e preconceito.

É aqui que o fascismo entra em jogo. Onde a representação colapsa ou gira em loops precipitados e feedbacks, o fascismo aparentemente oferece respostas simples. É o botão de pânico para bloquear remanescentes irritantes da realidade.

Por acabar, aparentemente, com as complicações da representação, o fascismo consegue ofuscar aquilo que é a maior forma contemporânea de representação especulativa: seu ponto de colapso, ou de impacto. $\mathrm{O}$ choque em si é de uma só vez super-representado e não representado. Um ponto cego cheio de desilusão e morte. A divisão irreversível dos caminhos em relação à realidade empírica.

A boa notícia para os fascistas é que sua ideologia é muito compatível com os paradigmas da economia contemporânea - porque ela ressoa perfeitamente a ideologia na qual a sociedade é nada e a ganância individual e a vontade de poder são tudo. Em que tribos e o tumulto imperam e estereótipos ultrapassados são hiperventilados. Especialmente em uma era de jogos de tiro em primeira pessoa e fanatismo online, o fascismo parece ser um complemento ideal para o capitalismo overdrive: uma vantagem forjada para os Arianos. Ele não só promete reintroduzir um (completamente especulativo) referente para o valor, nomeadamente raça e cultura, como, de forma conveniente, promete a seu público alvo que ele estará no mais alto escalão da divisão de classe, porque trabalhos sujos e mal pagos serão jogados aos "sub-humanos". Ele apresenta uma aparente alternativa à brutal igualdade da democracia liberal, em que se presume que todos vão "conseguir" ou falhar, apresentando-se como verdade autoevidente. No fascismo, a igualdade abstrata do capitalismo liberal é abolida pelo colapso da classe em raça. É a ideologia perfeita para os Arianos preguiçosos: você aproveita todos os benefícios do capitalismo sem, na verdade, ter que trabalhar. 
Nesse ponto reconhecemos que as palavras "Ariano" e "raça" podem ser substituídas por outros jargões "copia-e-cola" que compartilham premissas semelhantes. A maioria dos ataques terroristas da última década foram, na verdade, cometidos por extremistas de direita Hito Steyerl: três capítulos de Arte "Duty Free":

Arte na Era da Guerra Civil que queriam que suas respectivas culturas se mantivessem "puras" e exclusivas; que odeiam mulheres, comunistas e, sobretudo, minorias (isto é, minorias do ponto de vista deles) e cultivam uma ideologia centrada em torno da masculinidade à base de testosterona. Nem todas essas ideologias são fascistas, e não há razão em tentar resumi-las a essa noção. Mas todas elas tentam substituir a igualdade por uniformidade seja lá como eles definam esta última.

Mas é aí que está o ponto. Nenhum dos pontos sobre os quais eu escrevi levam necessariamente ao fascismo. Eles apresentam um contexto facilitador para sua emergência: não levam inevitavelmente a isso. A razão é simples. As pessoas têm a escolha. Qualquer um pode escolher entre tornar-se um fascista ou não. E a maioria das pessoas, felizmente, escolheram, até agora, não ser.

Pode-se escolher também não ignorar o problema. Ao invés de negar esses desafios, nós deveríamos enfrentá-los. Deveríamos encarar a completa confusão da realidade, reintroduzindo pesos e contrapesos, renegociando valor e informação, insistindo em representação e solidariedade humana. Isso também inclui reconhecer o fascismo real e se opor a ele e seus incontáveis derivativos e franquias. Negar sua existência significa render-se a um novo paradigma emergente de póspolítica e pós-democracia; à completa inversão da realidade. 


\begin{abstract}
309
ARS Bibliografia

ano 18

n. 39 KARATANI, Kojin. Transcritique: On Kant and Marx. Cambridge: MIT Press, 2003.
\end{abstract}

